\title{
Targeting the PD1/PD-L1 axis in melanoma: Biological rationale, clinical challenges and opportunities
}

\author{
Barbara Merelli ${ }^{\mathrm{a}}$, Daniela Massi ${ }^{\mathrm{b}}$, Laura Cattaneo ${ }^{\mathrm{c}}$, Mario Mandalà ${ }^{\mathrm{a}, *}$ \\ ${ }^{a}$ Unit of Medical Oncology, Department of Oncology and Hematology, Papa Giovanni XXIII Hospital, Bergamo, Italy \\ b Division of Pathological Anatomy, Department of Surgery and Translational Medicine, University of Florence, Italy \\ ${ }^{\mathrm{c}}$ Division of Pathological Anatomy, Papa Giovanni XXIII Hospital, Bergamo, Italy
}

Accepted 15 August 2013

\section{Contents}

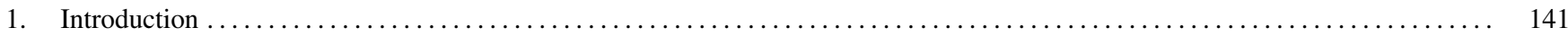

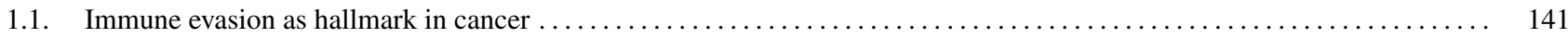

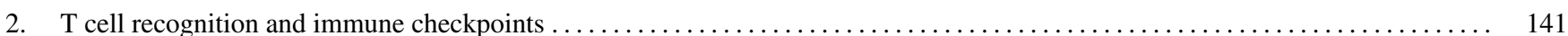

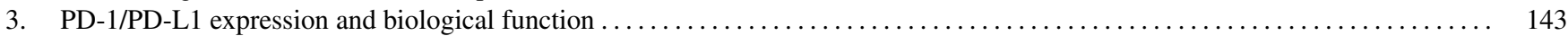

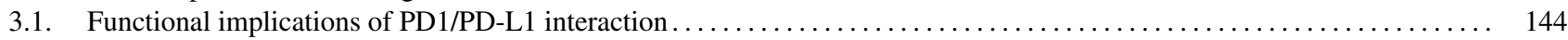

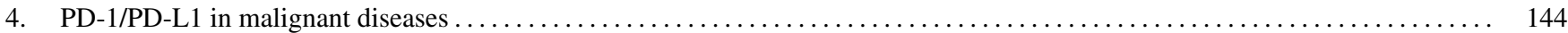

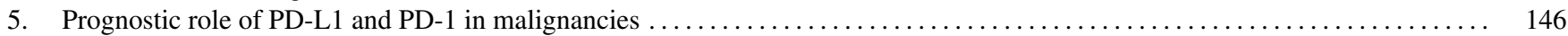

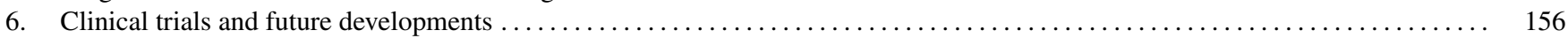

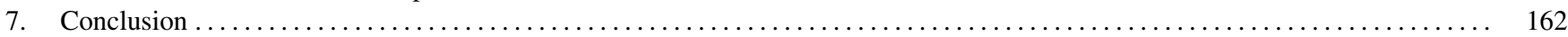

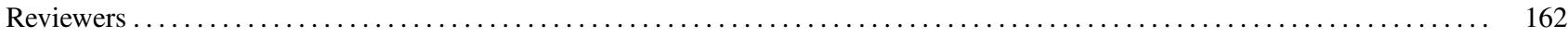

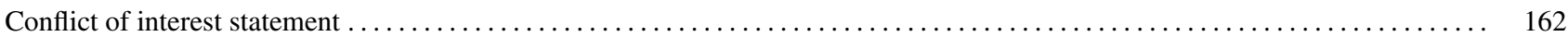

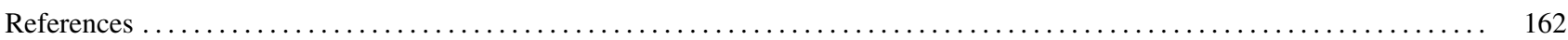

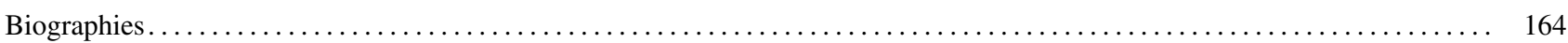

\begin{abstract}
A dynamic interplay exists between host and tumor, and the ability of the tumor to evade immune recognition often determines the clinical course of the disease. Significant enthusiasm currently exists for a new immunotherapeutic strategy: the use of immunomodulatory monoclonal antibodies that directly enhance the function of components of the anti-tumor immune response such as $\mathrm{T}$ cells, or block immunologic checkpoints that would otherwise restrain effective anti-tumor immunity. This strategy is based on the evidence that development of cancer is facilitated by the dis-regulation and exploitation of otherwise physiological pathways that, under normal circumstances, down-regulate immune activation and maintain tolerance to self. Among these pathways an important role is covered by the Programmed death-1 (PD1)/PD-Ligand (L) 1 axis. An emerging concept in cancer immunology is that inhibitory ligands such as PD-L1 are induced in response to immune attack, a mechanism termed "adaptive resistance". This potential mechanism of immune resistance by tumors suggests that therapy directed at blocking the interaction between PD-1 and PD-L1 might synergize with other treatments that enhance endogenous antitumor immunity. The anti-PD-1 strategy can be effective in several solid tumors such as renal cell carcinoma (RCC) or non-small cell lung cancer (NSCLC), however in this review we summarize the biological role of PD-1/PD-L1 on cancer by focusing our attention in the biological rationale, clinical challenges and opportunities to target the PD-1/PD-L1 axis in melanoma.
\end{abstract}

(C) 2013 Elsevier Ireland Ltd. All rights reserved.

Keywords: PD-1; PD-L1; Melanoma

\footnotetext{
* Corresponding author at: Unit of Medical Oncology, Department of Oncology and Haematology, Papa Giovanni XXIII Hospital, Piazza OMS 1, 24100 Bergamo, Italy. Tel.: +39 035 2673687; fax: +39 0352674985 .

E-mail addresses: bmerelli@hpg23.it (B. Merelli),daniela.massi@unifi.it (D. Massi), lcattaneo@hpg23.it (L.Cattaneo), mariomandala@tin.it (M. Mandalà).
} 


\section{Introduction}

\subsection{Immune evasion as hallmark in cancer}

Cellular transformation and tumor development result from an accumulation of mutational and epigenetic changes that alter normal cell growth and survival pathways [1]. In 2000, Hanahan and Weinberg reported six biological capabilities (hallmarks) acquired during the multistep development of human tumors: sustaining proliferative signaling, evading growth suppressors, resisting cell death, enabling replicative immortality, inducing angiogenesis, and activating invasion and metastasis [2]. In the last two decades, based on the emergence of new experimental data, two further hallmarks have been added to this list: reprogramming of energy metabolism and evading immune destruction [3].

This Copernican revolution had its foundation on the awareness that complete knowledge of cancer development cannot be achieved without recognizing the importance of the tumor microenvironment, a very important part of which is played by the immune system. A dynamic interplay exists between host and tumor, and the ability of the tumor to evade immune recognition (immune surveillance) often determines the clinical course of the disease [4].

The concept of cancer immune surveillance is based on the hypothesis that the immune system can suppress the development or progression of spontaneous malignancies [5]. Several data, first from animal models and later from studies in cancer patients, confirmed this original concept that the immune system can recognize and reject tumors, supporting the hypothesis that immune evasion by cancer cells plays an important role in the development and progression of tumors [6].

Based on this biological background, cancer immunotherapy focuses on the development of agents that can activate the immune system to recognize and kill tumor cells. However, until recently, all the efforts to therapeutically modulate the immune system were tempered by disappointing results from clinical trials with cancer vaccines and biochemotherapy regimens, as well as by the low response rates and high toxic effect associated with these two strategies [7-14]. A third approach known as adoptive cell therapy has shown clinical benefit for some patients although technical aspects and the complexity of the procedures have limited more widespread use [15]. Despite the initial lack of clinical success, extensive research over the past twenty years yielded the identification of innovative ways to manipulate the immune response to cancer.

The regulation of the immune system depends on a fine control system in which a key role is played by cellular receptors that ensure the activation or inhibition of cells involved in the control of infections and tumors and development of autoimmunity. Some of these mechanisms are activating and dictate whether the response arises, while others play the role of powerful repressors. Antagonist antibodies acting on such repressors result in enhanced immune responses, a goal that may also be achieved with agonist antibodies acting on the activating receptors.

More recently, significant enthusiasm arose for a fourth immunotherapeutic strategy: the use of immunomodulatory monoclonal antibodies that directly enhance the function of components of the anti-tumor immune response such as $\mathrm{T}$ cells or block immunologic checkpoints that would otherwise restrain effective anti-tumor immunity. This strategy is based on the evidence that development of cancer is enabled by the dis-regulation and exploitation of otherwise physiological pathways that, under normal circumstances, down-modulate immune activation and maintain tolerance to self. A series of therapeutic agents are under clinical development, and one of them, which is directed at the CTL-associated antigen 4 (CTLA-4) inhibitory receptor (Ipilimumab, Yervoy ${ }^{\circledR}$ ), has been approved for the treatment of metastatic melanoma. The list of antagonist agents acting on repressors under development includes anti-CTLA-4, anti-Programmed death-1 (PD-1), anti-PD-Ligand 1 (L1) or (B7-H1), anti-KIR (killer cell Ig-like receptor), and antiTGF- $\beta$. Agonist antibodies currently being investigated in clinical trials target CD40, CD137 (4-1BB), CD134 (OX40), and glucocorticoid-induced TNF receptor (GITR) (Fig. 1). Among these pathways an important role is covered by two immunologic checkpoints: the CTLA-4 and the PD-1/PD-L1 axis.

An emerging concept in cancer immunology is that inhibitory ligands such as PD-L1 are induced in response to immune attack, a mechanism termed adaptive resistance. This potential mechanism of immune resistance by tumors suggests that therapy directed at blocking interaction between PD-1 and PD-L1 might synergize with other treatments that enhance endogenous antitumor immunity.

In this review we summarize the biological role of PD1/PD-L1 in cancer by focusing our attention on the biological rational, clinical challenges and opportunities to target the PD-1/PD-L1 axis in melanoma.

\section{T cell recognition and immune checkpoints}

Induction of immune response requires $\mathrm{T}$ cells to receive two sets of signals from antigen-presenting cells: the $\mathrm{T}$ cell receptor must recognize complexes of $\mathrm{MHC}$ with the antigen on the surface of an antigen-presenting cell (APC). T cells and the $\mathrm{T}$ cell receptor complex do not respond to antigen in solution, but even for the specific antigen they only respond to antigen-MHC complexes on the cell surface. This interaction is necessary, but not sufficient, for $\mathrm{T}$ cell activation.

$\mathrm{T}$ cell activation also requires a co-stimulatory signal involving interaction of CD28 on the T cell with CD80 or CD86 (B7 family genes) on the APC, which promotes $\mathrm{T}$ cell clonal expansion and cytokine secretion [16]. CD28 activates a signal transduction pathway acting through Phosphatidylinositide 3-kinases (PI3K), lymphocyte-specific protein tyrosine kinase (Lck) and adaptor proteins GRB2 


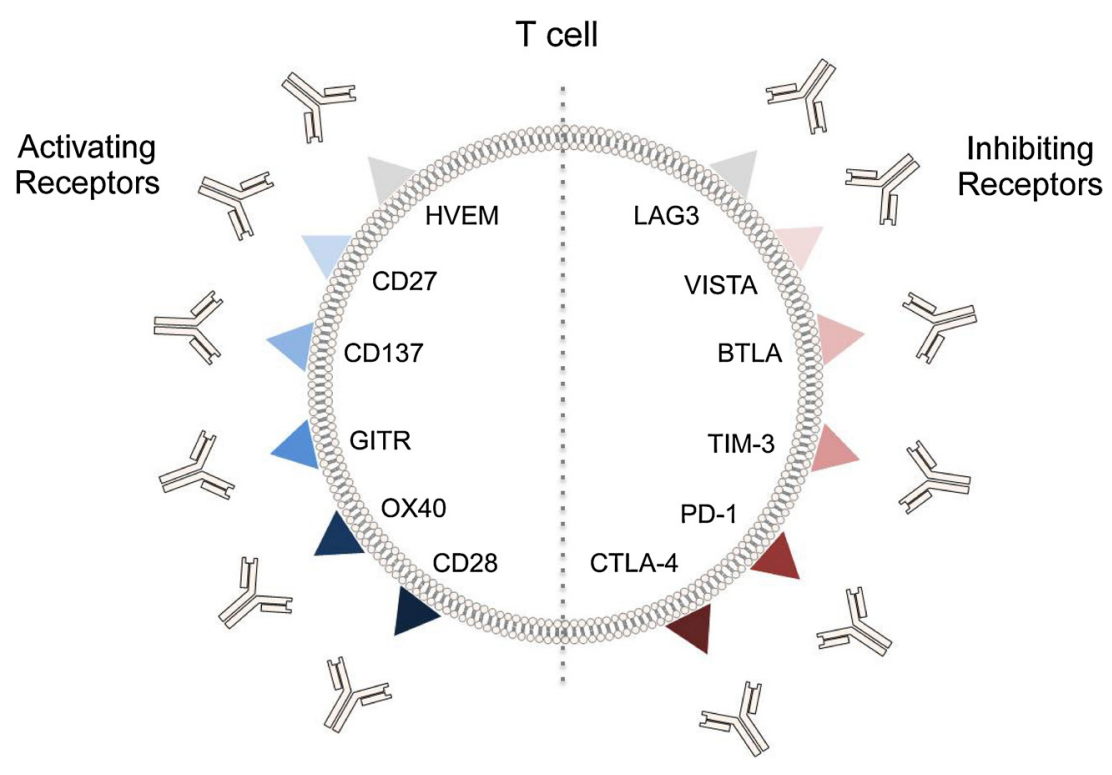

Fig. 1. Agonist antibodies (on the left) and antagonist antibodies (on the right). Antagonist agents under development acting on repressors include anti-CTLA-4 and anti-Programmed death-1 (PD-1).

and GRB2-related adaptor protein (Grb-2/ITK) to provide its co-stimulatory signal for $\mathrm{T}$ cell activation.

T cell-mediated immunity is regulated by balancing stimulatory and inhibitory signals that regulate the response [17]. In the absence of co-stimulatory molecules, the $\mathrm{T}$ cells enter an unresponsive state known as clonal anergy in which the $\mathrm{T}$ cells are incapable of providing antigen-specific immune responses [18].

In physiological conditions, immune checkpoints are crucial for maintaining self-tolerance and for protecting tissues from the damage of the immune response to pathogenic infection.

There is evidence that tumors resist immune attack by inducing tolerance toward tumor-specific $\mathrm{T}$ cells and by expressing ligands that bind inhibitory receptors such as immune checkpoints. Tumors can result in deregulation of the immune-checkpoint proteins and develop a mechanism for immune resistance, especially against $\mathrm{T}$ cells that are specific for tumor antigens [19].

Preliminary clinical data show that antibody blockage of immune checkpoints can substantially enhance therapeutic antitumor immunity $[19,20]$. Unlike conventional antibodies used for the treatment of tumors, antibodies that block immune checkpoints do not bind directly to the tumor cells, but target lymphocyte receptors or their ligands, in order to modulate their antitumor activity.

Several immunologic treatment options, such as the induction of an immune response or the administration of antibodies, have been investigated in melanoma and have shown interesting results [21]. CTLA-4 and PD-1 are the two most investigated immune checkpoint receptors in melanoma and cancer immunotherapy (Table 1) [22]. CTLA-4 is an inhibitory membrane receptor expressed exclusively on $\mathrm{T}$ cells, where it primarily regulates the amplitude of the early stages of $\mathrm{T}$ cell activation, counteracting the activity of the $\mathrm{T}$ cell co-stimulatory receptor, CD28.

As reported above, the engagement of the $\mathrm{T}$ cell antigen receptor by itself is not sufficient for full $\mathrm{T}$ cells activation; a second co-stimulatory signal is required. This co-stimulation is mediated by engagement of CD28 on the T cell surface by members of the B7 family on APC [23].

These co-stimulatory molecules are integral membrane proteins expressed on several cells with APC function. These molecules, including B7.1 (CD80) and B7.2 (CD86), bind to other ligands on $\mathrm{T}$ cells and provide the second signal for T-cells activation. Limited expression of B7 on APCs is a mechanism for maintenance of peripheral $\mathrm{T}$ cells tolerance, ensuring that $\mathrm{T}$ cells activation can only be stimulated by appropriate cells [24].

Interestingly, tumor cells do not express B7, and this contributes to their poor capacity to induce immune responses $[25,26]$. After activation, T cells express CTLA-4, a close homologue to CD28. CTLA-4 binds members of the B7 family with a much higher affinity than CD28 [27]. Accordingly, CTLA-4 expression on the surface of T cells decreases the activation of $T$ cells by competing with $\mathrm{CD} 28$ for binding with CD80 and CD86. CTLA-4 exerts distinct effects on the two major subsets of CD4+ T cells: down-modulation of helper $\mathrm{T}$ cell activity and enhancement of regulatory $\mathrm{T}\left(T_{\mathrm{Reg}}\right)$ cell immunosuppressive activity.

The specific signaling pathways by which CTLA- 4 blocks $\mathrm{T}$ cell activation are still under investigation, although a number of studies suggest that activation of the protein phosphatases, SHP2 (also known as PTPN11) and PP2A, is important in counteracting kinase signals that are induced by TCR and CD28.

The central role of CTLA-4 for keeping $\mathrm{T}$ cell activation in check is dramatically demonstrated by the lethal 
Table 1

Similarities and differences between CTLA-4 and PD-1.

\begin{tabular}{|c|c|c|}
\hline & PD-1 & CTLA-4 \\
\hline Biological function & Inhibitory receptor & Inhibitory receptor \\
\hline Expression on & $\begin{array}{l}\text { Activated T cells, activated B cells, activated NK } \\
\text { cells, TILs in different tumor types }\end{array}$ & $\begin{array}{l}\mathrm{T} \text { cells at the time of their initial response to antigen } \\
\text { (activated CD8+ effector T cells) }\end{array}$ \\
\hline Major role & $\begin{array}{l}\text { - Limitation of } \mathrm{T} \text { cells activity in peripheral tissues } \\
\text { following inflammatory responses } \\
\text { - Limitation of autoimmunity }\end{array}$ & Regulation of the early stage of $\mathrm{T}$ cells activation \\
\hline Ligands & $\begin{array}{l}\text { - PD-L1 (B7-H1/CD274) } \\
\text { - PD-L2 (B7-CD/CD273) }\end{array}$ & $\begin{array}{l}-\mathrm{CD} 80(\mathrm{~B} 7.1) \\
-\mathrm{CD} 86(\mathrm{~B} 7.2)\end{array}$ \\
\hline Mechanism of action & $\begin{array}{l}\text { - PD-1 binds to the ligand } \\
\text { - Recruitment of phosphatase SHP-2 } \\
\text { - Decreased expression of the cell survival protein } \\
\text { Bcl-xL } \\
\text { - PD-1 inhibits kinases (PI3K/AKT) that are } \\
\text { involved in T cells activation }\end{array}$ & $\begin{array}{l}\text { - CTLA-4 interacts with the ligand } \\
\qquad \\
\text { - Binding with PI3K, phosphatases SHP-2 and } \\
\text { PP2A } \\
\text { - Blockade of lipid-raft expression }\end{array}$ \\
\hline
\end{tabular}

NK cells, natural kill cells; CTLA-4, cytotoxic T-lymphocyte antigen 4; PD-1, Programmed death-1; PD-L1, Programmed cell death 1 ligand 1; PI3K, Phosphatidylinositide 3-kinase.

systemic immune hyperactivation phenotype of CTLA-4knockout mice.

In experimental models, mice rapidly develop lymphoproliferative disease with multiorgan lymphocytic infiltration and tissue destruction, including particularly severe myocarditis and pancreatitis, and die at 3-4 weeks of age [28]. The severe phenotype of mice lacking CTLA-4 implies a critical role for CTLA-4 in down-regulating T cell activation and maintaining immunologic homeostasis. In the absence of CTLA-4, T cells are activated, can spontaneously proliferate, and may mediate lethal tissue injury.

\section{PD-1/PD-L1 expression and biological function}

The PD- 1 receptor is a $50-55 \mathrm{kDa}$ type I transmembrane glycoprotein of the Ig superfamily, with an extracellular domain showing 21-33\% sequence identity with CTLA-4, CD28 and the inducible co-stimulatory (ICOS) molecule, but distinct function and ligand specificity $[29,30]$. PD-1 shows an extracellular IgV region, a transmembrane domain, and an intracellular tail. The cytoplasmic domain presents two tyrosine residues: one represents an immunoreceptor tyrosine-based inhibitory motif (ITIM), and the other an immunoreceptor tyrosine-based switch motif (ITSM) that may recruit phosphatases, similar to other negative regulators [31,32].

PD-1 expression is mostly detected at the cell surface (membrane) level, where it exerts its function of inhibitory receptor, however, PD-1 expression has also been observed in the cell cytoplasm [33]. It is as yet unclear whether cytoplasmic PD-1 exerts biological functions or merely serves as a repository of the protein, allowing an immediate response as soon as its expression at the membrane is requested.

PD-1 is expressed on CD4-/CD8 - thymocytes in transition to $\mathrm{CD} 4+/ \mathrm{CD} 8+$ stage and on mature $\mathrm{T}-$ and $\mathrm{B}$ cells upon activation, while it is not detectable on resting $\mathrm{T}$ cells. Thus, in comparison with CTLA-4, PD-1 has a slightly broader expression profile, also present on activated myeloid lineage cells such as monocytes, dendritic cells and NK cells [34,35]. PD-1 is quickly up-regulated on T lymphocytes after exposure to cognate antigen and its expression is controlled by several cytokines including IFN- $\gamma$, IL-2, IL-7, IL-15, and IL-21 [36]. Upon antigen clearance, PD-1 expression wanes accordingly. In normal tissues, PD-1 signaling in T cells regulates immune responses to diminish damage, and counteracts the development of autoimmunity by promoting tolerance to self-antigens.

Most biological functions of PD-1 have been elucidated by generating PD-1-deficient mice with gene knockout technology. PD-1-knockout mice spontaneously develop phenotypes of lymphoproliferative autoimmune diseases, accompanied by a marked accumulation of inflammatory cells in affected organs, including CD4+ and CD8+ $\mathrm{T}$ cell subsets [37]. Autoimmune manifestations in PD-1 mice are different from those observed in CTLA-4 -/- mice, which die at 3-4 weeks of age from massive lymphocytic infiltration and tissue destruction in multiple organs [38]. The PD-1 related autoimmune phenomena are overall milder and less frequent than those observed following anti-CTLA-4 therapy. Table 1 summarizes the main differences between CTLA-4 and PD-1.

Two ligands for PD-1, designated PD-1 ligand 1 (PD-L1; B7-H1/CD274) and PD-1 ligand 2(PD-L2; B7-DC/CD273), have been identified based on the similarity to other B7 
superfamilies. PD-L1 and PD-L2 are type I transmembrane glycoproteins composed of $\mathrm{IgC}$ - and $\mathrm{IgV}$-type extracellular domains that present $40 \%$ amino acid identity sequence [34,39-41]. In contrast to the limited expression of PDL2 on activated macrophages [42], PD-L1 is more broadly expressed on immune and non-hematopoietic cells. Specifically, PD-L1 is constitutively expressed on T- and B cells, macrophages, and dendritic cells, and is upregulated upon stimulation by proinflammatory cytokines including IFN.

Despite the fact that PD-L1 mRNA has been reported in a wide range of human healthy tissues and cell types (with high expression in placenta, heart, lung and liver, low expression in spleen, lymph nodes and thymus, and no expression in the central nervous system), constitutive PD-L1 protein is much less ubiquitous in normal tissues. PD-L1 protein has also been reported to be expressed on parenchymal cells such as pancreatic islet cells, endothelial cells, muscle cells and trophoblasts. Discrepancies between mRNA and protein expression are most likely attributable to a series of posttranscriptional controls that have not yet been completely clarified [43].

PD-L1-deficient mice do not develop spontaneous autoimmune diseases, mild-to-moderate levels of lymphocyte accumulation are evident in the kidneys, liver, and lung, with a predominant $\mathrm{CD} 3+/ \mathrm{CD} 8+$ component exhibiting significantly decreased apoptosis [44]. Although the mechanism underlying selective accumulation of CD8+ T cells in PDL1-/- mice remains to be clarified, these findings implicate a role for PD-L1 in the maintenance of $\mathrm{T}$ and cell homeostasis in peripheral organs. Overall, these data support the hypothesis that the expression of this ligand in non-lymphoid tissue cells can prevent immune-mediated tissue damage [45].

\subsection{Functional implications of PD1/PD-L1 interaction}

PD-1/PD-L1 interaction inhibits T lymphocyte proliferation, survival, and effector functions, induces apoptosis of antigen-specific $\mathrm{T}$ cells, and promotes the differentiation of CD4+ T cells into Foxp3+ regulatory T cells. The mechanism by which PD-1 exerts the inhibitory effect has been partially explained. As soon as PD-L1 interacts with PD-1, there is a recruitment of Src homology region 2 domain-containing phosphatase-1 (SHP-1) and SHP-2, which dephosphorylate multiple members of the TCR signaling pathway. This abrogates downstream effects of T-cell activation, including cytokine production, cell-cycle progression, and the expression of survival proteins. Furthermore, the inhibition of RAS and PI3K/AK3 pathways cooperates to inhibit lymphocyte' function and survival (Fig. 2).

Considering that (1) PD-L1 is upregulated in hematopoietic and reticuloendothelial cells, in response to proinflammatory cytokines such as IFN- $\gamma$, and (2) PD- 1 is expressed to various degrees on activated $\mathrm{T}$ cells, it is reasonable to speculate that the co-expression of ligand and receptor in inflamed tissues mitigates against collateral tissue destruction by $\mathrm{T}$ cells at these sites. The PD-1/PD-L1 axis would therefore be important in mitigating the inflammatory response and in turn potential autoimmune foci resulting from the dysregulation of the effector phase of the immune response. This mechanism is important in various physiological and pathological processes including feto-maternal tolerance, graft-versus-host disease, and various autoimmune diseases.

Another piece of the puzzle for understanding the central role of the PD-1/PD-L1 axis in the immune response derives from studies evaluating the developing of $\mathrm{T}$ cell exhaustion. While PD-1 is expressed on activated lymphocytes during an acute inflammatory process to limit tissue damage and, as soon as the exogenous stimulus is cleared, the PD-1 wanes accordingly, the persistent antigen exposure may prevent the down-regulation of PD-1. Since the immune response plays an important role in staving off cancer, mechanisms of immunosuppression hinder productive anti-tumor immunity. T cell exhaustion is one such mechanism. PD-1 has been identified as a marker of exhausted $\mathrm{T}$ cells in chronic disease states, including cancer, and blockade of PD-1-PD-L1 interactions has been shown to partially restore $\mathrm{T}$ cell function. The development of $\mathrm{T}$ cell exhaustion translates into a major immune resistance and promotes the immune evasion.

\section{PD-1/PD-L1 in malignant diseases}

Via immunohistochemistry, PD-L1 is constitutively expressed in many human cancers [46]. The finding that PDL1 is commonly upregulated on many different tumor types including melanoma [47], ovarian cancer [48], lung cancer [49], clear cell renal carcinoma [50], urothelial carcinoma [51], squamous cell carcinomas of the head and neck [52,53], esophageal cancer [54], cervical cancer [55], breast carcinoma [56], pancreatic cancer [57], gastric cancer [58], Wilms tumor [59] and glioblastoma [60], and that PD-1 is expressed in TILs, has created an important rationale for mAb blockade of this pathway for cancer immunotherapy.

In addition to expression on tumor cells, PD-L1 can be detected on cells located in the tumor microenvironment, and high levels of PD-L1 expression have been reported in TILs and tumor-associated macrophages $[49,61,62]$. However, the ultimate meaning of the PD-L1 expression on tumor cells and other cells in the microenvironment remains to be fully determined.

PD-L1 expression on cancer cells may be an adaptive response to immune attack and induced by cytokines, or constitutive as a result of oncogenic processes, as occurs in BRAFV600 mutated melanoma. The role of oncogenes to drive immunosuppression has been suggested but not as yet clarified so far.

Interestingly, in melanoma models there is evidence that BRAFV600 mutation, along with the STAT3 signal, is essential for immune evasion by human melanomas. Recently, Khalili et al. demonstrated that the activation of the MAPK signaling pathway in melanoma cells by oncogenic $B R A F^{V 600 E}$ leads to the production of interleukin 1 (IL-1) $\alpha / \beta$ 


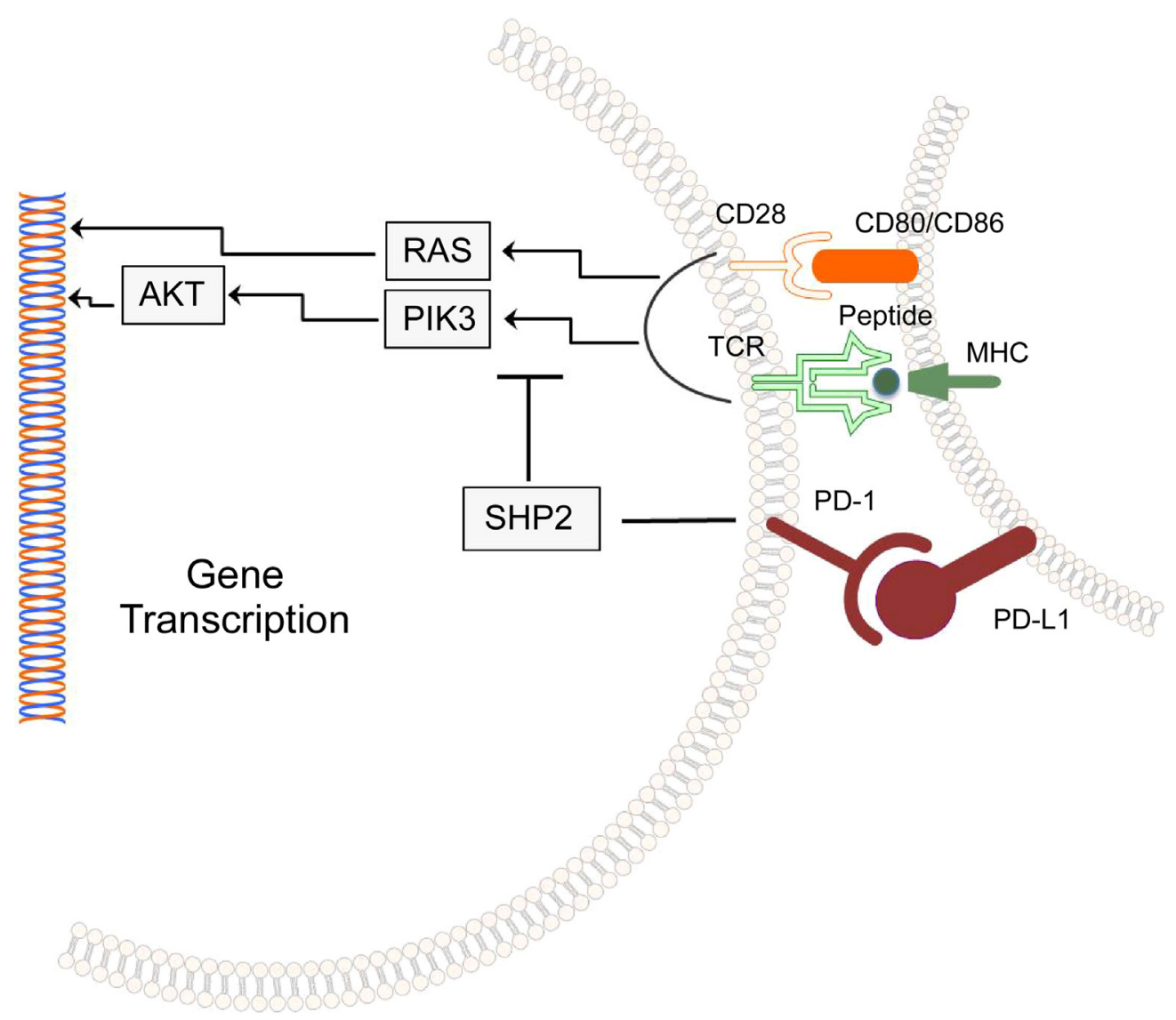

Fig. 2. Upon interaction of PD-L1 with PD-1, there is a recruitment of Src homology region 2 domain-containing phosphatase-1 (SHP-1) and SHP-2, which dephosphorylate multiple members of the TCR signaling pathway. This abrogates downstream effects of T-cell activation, including cytokine production, cell-cycle progression, and the expression of survival proteins. The inhibition of RAS and PI3K/AK3 pathways cooperates to inhibit lymphocytes' function and survival.

[63]. Tumor-associated fibroblasts (TAFs) respond to IL-1 by upregulating an immunomodulatory transcriptional program resulting in the production of $\mathrm{COX}-2, \mathrm{PD}-1$ ligands, and chemokines, as well as in the amplification of IL-1 signaling (Fig. 3). Collectively, these factors and signaling circuitries suppress cytotoxic $\mathrm{T}$ lymphocyte functions and ultimately promote tumor growth. These data highlight the hypothesis that both mechanisms (constitutive and induced) may concomitantly contribute to the PD-L1 expression on tumor cells and in other cells in the microenvironment, potentially fueling an immune tolerance state.

However, most of the data so far reported in literature are heterogeneous in terms of PD-L1 expression, variability in the assays and cell immunolocalization, as well as cut-off values for positive versus negative PD-L1 immunohistochemical expression. Furthermore, PD-L1 expression has been investigated in primary tumors and metastatic tissue samples, but little conflicting data is available with regard to the concordance/discordance of PD-L1 and PD-1 immunohistochemical expression in paired human tissues from primary melanomas and respective metastases.

Another role in this complicated puzzle is played by PD1. Similar to exhausted virus antigen-specific $T$ cells, which have been reported in chronic viral infections, the majority of TILs in melanoma express high levels of PD-1 compared with $\mathrm{T}$ cells from normal tissues and peripheral blood.

Previous studies on several human cancer types elegantly showed that overexpression of PD-L1 in tumor cells may allow immune evasion [46]. When PD-L1 binds with PD-1 receptor on T-cells, T-cell function is compromised through induction of apoptosis, suppression of proliferation, and inhibition of $\mathrm{T}$-cell cytokines release, such as IFN- $\gamma$, IL-4 and IL-2. Furthermore, the PD-1/PD-L1 interaction inhibits $\mathrm{T}$ lymphocyte proliferation, survival and cytokines secretion, promotes the differentiation of CD4positive/CD25-negative/Foxp3-negative T cells into Foxp3+ regulatory $\mathrm{T}$ cells (Treg), and induces apoptosis of tumorspecific T cells. Treg cells allow tumor cells to grow locally, and PD1/PD-L1 pathway on tumor cells causes immunosuppression by PD-L1-induced Treg cells.

One study showed that the majority of CD8+ TILs specific for the melanoma antigen MART-1 expresses significant levels of PD-1 compared with lower expression on MART-specific T cells from the peripheral blood of the same patients [64]. PD-1 expression by TILs in melanoma correlated with an exhausted T cell phenotype and impaired 


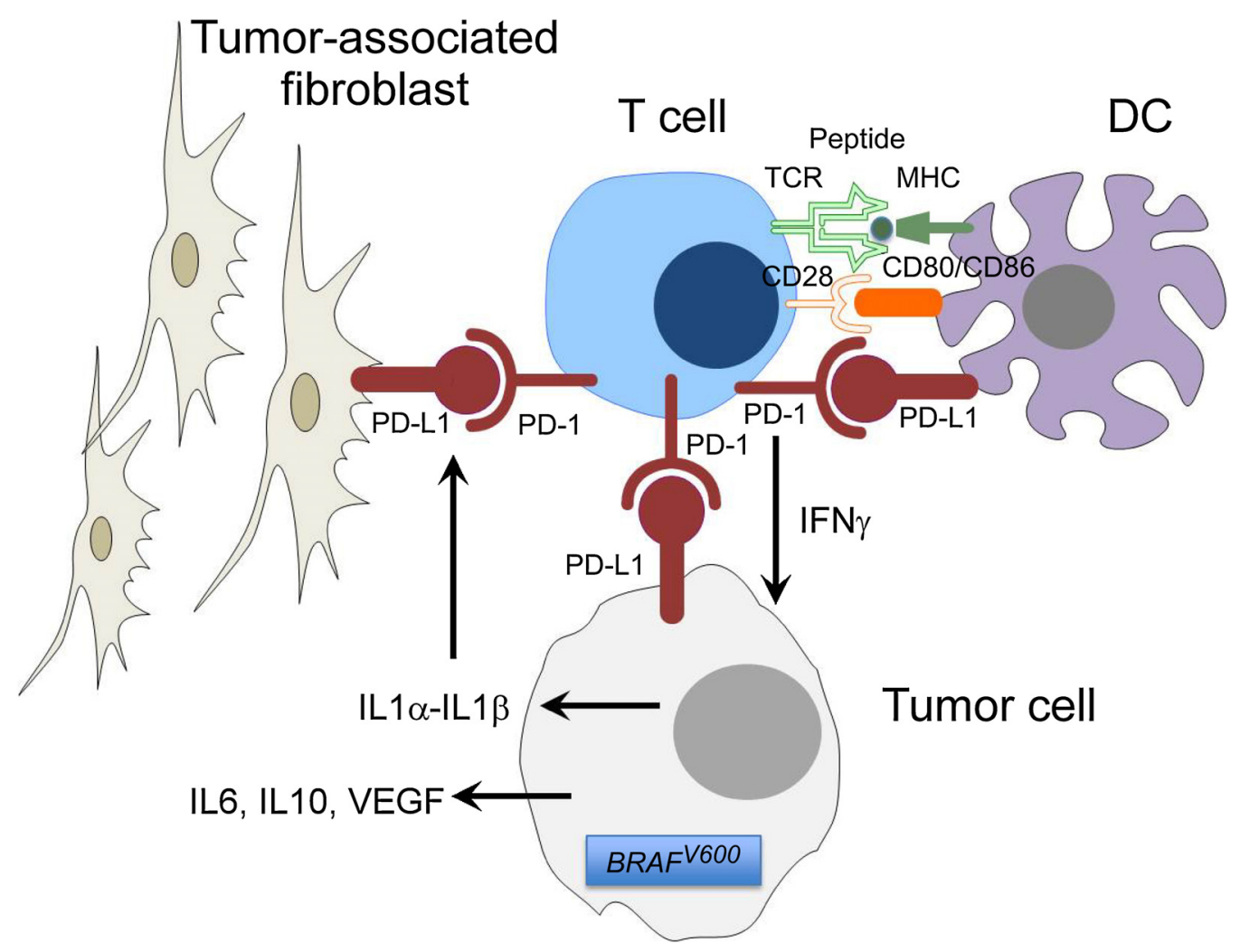

Fig. 3. The activation of the MAPK signaling pathway in melanoma cells by oncogenic $B R A F^{V 600 E}$ leads to the production of interleukin 1 (IL-1) $\alpha / \beta$. Tumorassociated fibroblasts (TAFs) respond to IL-1 by upregulating an immunomodulatory transcriptional program resulting in the production of COX-2, PD-1 ligands and chemokines as well as in the amplification of IL-1 signaling. Collectively, these factors and signaling circuitries suppress cytotoxic $\mathrm{T}$ lymphocyte (CTL) functions and ultimately promote tumor growth.

effector function. These data underscore once again that the assessment of circulating lymphocytes does not necessarily reflect what happens in the tumor microenvironment, at the biological interface between immune system and cancer. Therefore, the evaluation of the immunological profile in the circulation may be misleading in the assessment of the interaction between lymphocytes, APC, other cells in the microenvironment, and tumor cells.

In conclusion, all the above reported data suggest that the constitutively or the cytokine-induced PD-L1 expression would provide a selection advantage of cancer cells by inhibiting tumor-specific recognition and elimination by $\mathrm{T}$ cells. PD-L1/PD- 1 axis is a potential point of contact between target molecules (BRAFV600), immune evasion and tumor growth. Therefore, therapeutic antibodies that block PD-1 in order prevent the inhibitory interaction between PD-1 and PD-L1 may partially circuit the cancer immune evasion and elicit the immune system to recognize and kill tumor cells.

\section{Prognostic role of PD-L1 and PD-1 in malignancies}

Tables 2 and 3 summarize studies on the prognostic role of PD-L1 and PD-1 in different tumor types. Overall, the results published so far are heterogeneous in terms of patient' selection criteria and methodology used for immunohistochemical analysis. Specifically, difficulties in comparing results arise from the following considerations: (i) available data are retrospective; (ii) patients with different tumor stages have been included; (iii) primary or metastatic sites have been included; (iv) different tumor histotypes have been compared within the same studies; (v) different types of tissues have been evaluated (frozen versus paraffinembedded samples); (vi) monoclonal and/or polyclonal antibodies have been used; (vii) both cytoplasmic and/or membranous immunostaining have been evaluated to define positivity; and finally (viii) different scores of PD-L1 and/or PD-1 positivity have been reported. Thus, the prognostic role of PD-L1 and PD-1 in the context of different tumor types requires further investigation and only future studies will establish whether PD-L1 is an immune correlate and predictive marker for response to anti PD-1 antibody.

According to the aim of the present review we will focus on melanoma. At the time of the present manuscript, three studies reported the role of PD-L1 in melanoma patients.

Hino et al. evaluated the intensity of PD-L1 expression in melanoma specimens (59 primary tumors, 16 lymph nodes, and 4 in-transit metastases). By multivariate analysis, immunohistochemical PD-L1 expression correlated with Breslow thickness, disease free, and overall survival [47]. 
Table 2

PD-L1 expression and prognosis in malignancies.

\begin{tabular}{|c|c|c|c|c|c|c|}
\hline Author & $N^{\mathrm{a}}$ & Tumor & Tissues/Detection Method & Immunostaining & Antibody & Prognostic role \\
\hline Thompson [79] & 306 & Renal cell carcinoma & FFPE tissues/IHC & $\begin{array}{l}\text { Cell-surface membrane } \\
(\geq 5 \% \text { tumor staining = PD-L1 } \\
\text { positivity) }\end{array}$ & $\begin{array}{l}\text { Anti-PD-L1 } \\
\text { MoAb } \\
(5 \mathrm{H} 1)\end{array}$ & $\begin{array}{l}\text { Yes: } \\
\text { Association } \\
\text { PD-L1 positivity tumor/ } \\
\text { - Death } \\
\text { (RR, 3.92; } P<0.001) \\
\text { - Overall mortality } \\
\text { (RR, } 2.37 ; P<0.001) \\
\text { PD-L1 independent prognostic factor } \\
\text { of cancer-specific death }\end{array}$ \\
\hline Thompson [50] & 429 & Renal cell carcinoma & Fresh-Frozen tissues/IHC & $\begin{array}{l}\text { Cell-surface membrane } \\
(\geq 10 \% \text { tumor staining }=\text { PD-L1 } \\
\text { positivity })\end{array}$ & $\begin{array}{l}\text { Anti-PD-L1 } \\
\text { MoAb } \\
(5 \mathrm{H} 1)\end{array}$ & $\begin{array}{l}\text { Yes: } \\
\text { Association } \\
\text { PD-L1 positivity tumor/ } \\
\text { death } \\
\text { (RR, } 4.53 ; P<0.001) \\
\text { PD-L1 independent prognostic factor } \\
\text { of cancer-specific death }\end{array}$ \\
\hline Taube [66] & 150 & Melanoma & FFPE tissues/IHC & $\begin{array}{l}\text { Cell-surface membrane PD-L1 } \\
\text { expression } \\
\text { ( } \geq 5 \% \text { tumor staining = PD-L1 } \\
\text { positivity) }\end{array}$ & $\begin{array}{l}\text { Anti-PD-L1 } \\
\text { MoAb } \\
(5 \mathrm{H} 1) \\
\text { Anti-PD-L1 polyclonal Ab } \\
(4059)\end{array}$ & $\begin{array}{l}\text { Yes: } \\
\text { Association } \\
\text { PD-L1 positivity tumor/ } \\
\text { OS } \\
(P=0.032)\end{array}$ \\
\hline Gadiot [65] & 63 & Melanoma & FFPE tissues/IHC & $\begin{array}{l}\text { N/A } \\
\text { ( } \geq 1 \% \text { tumor staining = PD-L1 } \\
\text { positivity) }\end{array}$ & $\begin{array}{l}\text { Several Anti-PD-L1 } \\
\text { MoAbs } \\
\text { Anti-PD-L1 polyclonal Ab } \\
(4059)\end{array}$ & No \\
\hline
\end{tabular}


Table 2 (Continued)

\begin{tabular}{|c|c|c|c|c|c|c|}
\hline Author & $N^{\mathrm{a}}$ & Tumor & Tissues/Detection Method & Immunostaining & Antibody & Prognostic role \\
\hline Hino [47] & 59 & Melanoma & FFPE tissues/IHC & Cytoplasm area & $\begin{array}{l}\text { Anti-PD-L1 } \\
\text { MoAb } \\
\text { (27A2) }\end{array}$ & $\begin{array}{l}\text { Yes: } \\
\text { Association } \\
\text { PD-L1 positivity tumor/ } \\
\text { - OS } \\
(P=0.0402) \\
\text { - PFS } \\
(P=0.0522) \\
\text { PD-L1 independent prognostic factor } \\
\text { of OS and PFS }\end{array}$ \\
\hline Ohigashi [54] & 41 & Esophageal cancer & $\begin{array}{l}\text { Frozen tissues/IHC; } \\
\text { mRNA analysis (Real-time } \\
\text { quantitative PCR) }\end{array}$ & $\begin{array}{l}\text { Cell-surface membrane } \\
\text { or } \\
\text { Cytoplasm area } \\
(\geq 10 \% \text { tumor staining = PD-L1 } \\
\text { positivity) }\end{array}$ & $\begin{array}{l}\text { Anti-PD-L1 } \\
\text { MoAb } \\
\text { (MIH1) } \\
\text { Anti-PD-L2 } \\
\text { MoAb } \\
\text { (MIH18) }\end{array}$ & $\begin{array}{l}\text { Yes: } \\
\text { Association } \\
\text { - PD-L1 mRNA expression } \\
\text { positivity/ } \\
\text { OS } \\
(P=0.025) \\
\text { - PD-L2 mRNA expression } \\
\text { positivity/ } \\
\text { OS } \\
(P=0.003) \\
\text { - PD-L1 positivity and PD-L2 } \\
\text { positivity status/ } \\
\text { OS } \\
(P=0.0008) \\
\text { PD-L1 and PD-L2 = independent } \\
\text { Prognostic factors of OS }\end{array}$ \\
\hline $\mathrm{Wu}[58]$ & 102 & Gastric cancer & FFPE tissues/IHC & $\begin{array}{l}\text { Cytoplasm area } \\
\text { (some nuclear membrane } \\
\text { localization) }\end{array}$ & $\begin{array}{l}\text { Anti PD-L1 } \\
\text { MoAb } \\
(2 \mathrm{H} 11)\end{array}$ & $\begin{array}{l}\text { Yes: } \\
\text { Association } \\
\text { PD-L1 positivity tumor/ } \\
\text { OS }(P<0.01) \\
\text { PD-L1 }= \\
\text { independent prognostic factor of OS } \\
(\mathrm{RR}=2.803 ; P=0.040)\end{array}$ \\
\hline
\end{tabular}




\begin{tabular}{|c|c|c|c|c|c|c|}
\hline Konishi [49] & 52 & $\begin{array}{l}\text { Non-small cell lung } \\
\text { carcinoma }\end{array}$ & Frozen tissues/IHC & $\begin{array}{l}\text { Cell-surface membrane } \\
\text { and/or } \\
\text { Cytoplasm area } \\
\text { (focal or scattered pattern) }\end{array}$ & $\begin{array}{l}\text { Anti-PD-L1 } \\
\text { MoAb } \\
\text { (MIH1) } \\
\text { Anti-PD-L2 } \\
\text { MoAb } \\
\text { (MIH14) }\end{array}$ & No \\
\hline $\mathrm{Mu}[80]$ & 109 & $\begin{array}{l}\text { Non-small cell lung } \\
\text { carcinoma }\end{array}$ & FFPE tissues/IHC & $\begin{array}{l}\text { Cell-surface membrane } \\
\text { and/or } \\
\text { Cytoplasm area } \\
\text { (focal or scattered pattern) }\end{array}$ & $\begin{array}{l}\text { Anti-PD-L1 } \\
\text { (clone not specified) }\end{array}$ & $\begin{array}{l}\text { Yes: } \\
\text { Association } \\
\text { PD-L1 positivity tumor/ } \\
3 \text { years OS }(P=0.034)\end{array}$ \\
\hline Gao [81] & 240 & $\begin{array}{l}\text { Hepatocellular } \\
\text { carcinoma }\end{array}$ & FFPE tissues/IHC & $\begin{array}{l}\text { Cell-surface membrane } \\
\text { and/or } \\
\text { Cytoplasm area } \\
\text { (focal or scattered pattern) }\end{array}$ & $\begin{array}{l}\text { Anti-PD-L1 } \\
\text { MoAb } \\
\text { Anti-PD-L2 } \\
\text { MoAb }\end{array}$ & $\begin{array}{l}\text { Yes: } \\
\text { Association } \\
\text { PD-L1 positivity tumor/ } \\
\text { - DFS } \\
(P=0.047) \\
\text { - OS } \\
(P=0.029) \\
\text { PD-L1 independent prognostic factor } \\
\text { of DFS } \\
(P=0.015)\end{array}$ \\
\hline Cariani [82] & 42 & $\begin{array}{l}\text { Hepatocellular } \\
\text { carcinoma }\end{array}$ & $\begin{array}{l}\text { Frozen tissues/mRNA } \\
\text { analysis (Real Time } \\
\text { quantitative PCR) } \\
\text { FFPE tissues/IHC (on } 15 \\
\text { HCC samples) }\end{array}$ & Cytoplasm area & Anti-PD-L1 polyclonal Ab & $\begin{array}{l}\text { Yes: } \\
\text { Association } \\
\text { PD-L1 mRNA expression positivity/ } \\
\text { OS } \\
(P<0.05)\end{array}$ \\
\hline
\end{tabular}


Table 2 (Continued)

\begin{tabular}{|c|c|c|c|c|c|c|}
\hline Author & $N^{\mathrm{a}}$ & Tumor & Tissues/Detection Method & Immunostaining & Antibody & Prognostic role \\
\hline Zeng [83] & 109 & $\begin{array}{l}\text { HBV-related } \\
\text { Hepatocellular } \\
\text { carcinoma }\end{array}$ & FFPE tissues/IHC & $\begin{array}{l}\mathrm{NA} \\
(\geq 50 \% \text { tumor staining = PD-L1 } \\
\text { positivity) }\end{array}$ & $\begin{array}{l}\text { Anti-PD-L1 } \\
\text { MoAb }\end{array}$ & $\begin{array}{l}\text { Yes: } \\
\text { Association } \\
\text { PD-L1 positivity tumor/ } \\
\text { - TFS } \\
(P \leq 0.001) \\
\text { - OS } \\
(P \leq 0.001) \\
\text { PD-L1 independent prognostic factor } \\
\text { of TFS }(P \leq 0.001) \text { and OS } \\
(P=0.007)\end{array}$ \\
\hline Karim [55] & 115 & Cervical cancer & FFPE tissues/IHC & $\begin{array}{l}\text { Cell-surface membrane } \\
\text { (PD-L1/PD-L2) }\end{array}$ & $\begin{array}{l}\text { Anti-PD-L1 } \\
\text { MoAb } \\
\text { (5H1) } \\
\text { Anti-PD-L2 } \\
\text { MoAb } \\
\text { Anti-PD1 } \\
\text { MoAb }\end{array}$ & No \\
\hline Nomi [57] & 51 & Pancreatic cancer & $\begin{array}{l}\text { Frozen tissues/IHC } \\
\text { mRNA analysis (Real-time } \\
\text { quantitative PCR) }\end{array}$ & $\begin{array}{l}\text { Cell-surface membrane and } \\
\text { Cytoplasm area } \\
(\geq 10 \% \text { tumor staining = PD-L1 } \\
\text { positivity) }\end{array}$ & $\begin{array}{l}\text { Anti-PD-L1 } \\
\text { MoAb } \\
\text { (MIH1) } \\
\text { Anti-PD-L2 } \\
\text { MoAb } \\
\text { (MIH18) }\end{array}$ & $\begin{array}{l}\text { Yes: } \\
\text { Association } \\
\text { PD-L1 positivity tumor/ } \\
\text { OS } \\
(P=0.016) \\
\text { PD-L1 independent prognostic factor } \\
\text { of OS } \\
(P=0.022)\end{array}$ \\
\hline
\end{tabular}




\section{Cho [62]}

45 Oral squamous cell carcinoma

Hsu [84]

74 Nasopharyngeal carcinoma

Snap-frozen tissue
(28 samples)

Droeser [85] 1420

\section{Colorectal cancer}

FFPE tissues/IHC

FFPE tissues/IHC

(46 samples)

\section{FFPE tissues- \\ TMA/IHC}

$\begin{array}{ll}\text { Cell-surface membrane and/or } & \text { Anti-PD-L1 } \\ \text { Cytoplasm area } & \text { MoAb } \\ \text { (focal pattern) } & \text { (MIH1) }\end{array}$

Cell-surface membrane and/or

Cytoplasm area

NA

NA
(Score 2-3 tumor staining = PD-L1
positivity;
Intensity of PDL1
Staining=
Score 0: negative
Score 1: very weak expression
Score 2: moderate expression but
weaker than placenta)
Score 3: equivalent to or stronger
expression than placenta)

(ab82059)

\section{Anti-PD-L1}

$\mathrm{MoAb}$

(MIH1)

Anti-PD-L2

$\mathrm{MoAb}$

(MIH18)

Anti-PD-L1

$\mathrm{MoAb}$

(27A2)

Anti-PD-L1

(ab82059)
Yes:

Association:

PD-L1 positivity tumor/

- OS

$(P=0.021)$

- Post-resection recurrence $(P=0.026)$

Anti-PD-L1 polyclonal Ab No

Anti-human PD-1 polyclonal Ab

No

Polyclonal Ab

Yes:

Association

PD-L1 positivity tumor (MoAb)/

OS

$(P=0.0001)$

PD-L1 positivity tumor (polyclonal $\mathrm{Ab}) /$

OS

$(P=0.008)$

PD-L1 trend for independent prognostic factor $(P=0.052)$ 
Table 2 (Continued)

\begin{tabular}{|c|c|c|c|c|c|c|}
\hline Author & $N^{\mathrm{a}}$ & Tumor & Tissues/Detection Method & Immunostaining & Antibody & Prognostic role \\
\hline Hamanishi [48] & 70 & Ovarian cancer & FFPE tissues/IHC & $\begin{array}{l}\text { NA } \\
\text { (Score 2-3 tumor staining = PD-L1/ } \\
\text { PD-L2 positivity; } \\
\text { Intensity of PD-L1 and PDL2 } \\
\text { staining =-Score 0: negative } \\
\text {-Score 1: very weak expression } \\
\text {-Score 2: moderate expression but } \\
\text { weaker than placenta (PD-L1) and } \\
\text { tonsil (PD-L2) } \\
\text {-Score 3: equivalent to or stronger } \\
\text { expression than placenta or tonsil) }\end{array}$ & $\begin{array}{l}\text { Anti-PD-L1 } \\
\text { MoAb } \\
(27 A 2)\end{array}$ & $\begin{array}{l}\text { Yes: } \\
\text { PD-L1 independent prognostic factor } \\
\text { of: } \\
\text { - OS (RR, 4.26; 95\% CI, 1.39-12.94; } \\
P=0.011) \\
\text { - PFS (RR, 2.57; 95\% CI, 1.11-5.93; } \\
P=0.027)\end{array}$ \\
\hline Topalian [67] & 42 & $\begin{array}{l}18 \\
\text { Melanoma } \\
10 \\
\text { Non-small cell lung } \\
\text { carcinoma } \\
7 \\
\text { Colorectal cancer } \\
5 \\
\text { Renal cell carcinoma } \\
2 \\
\text { Prostate cancer }\end{array}$ & FFPE tissues/IHC & $\begin{array}{l}\text { NA } \\
(\geq 5 \% \text { tumor } \\
\text { staining = PD-L1 positivity) }\end{array}$ & $\begin{array}{l}\text { Anti-PD-L1 } \\
\text { MoAb } \\
\text { (5H1) }\end{array}$ & $\begin{array}{l}\text { Yes: } \\
\text { Association } \\
\text { Pretreatment PD-L1 positivity tumor/ } \\
\text { Objective Response after treatment } \\
\text { with anti-PD-1 antibody }\end{array}$ \\
\hline
\end{tabular}

IHC, immunohistochemistry; FFPE, formalin-fixed and paraffin-embedded; OS, overall survival; DFS, disease free survival; PFS, progression free survival; RR, risk ratio; Ab, antibody; MoAb, monoclonal antibody; TMA, tissue microarray; TFS, treatment free survival; NA, not applicable; PCR, polymerase chain reaction.

${ }^{a}$ Number. 
Table 3

PD-1 and prognosis in malignancies.

\begin{tabular}{llllll}
\hline Author & $\mathrm{N}^{\circ}$ & Tumor & $\begin{array}{l}\text { Tissues/detection } \\
\text { method }\end{array}$ & $\begin{array}{l}\text { Cell } \\
\text { immunolocalization/cut- } \\
\text { off for } \\
\text { positivity }\end{array}$ & Antibody \\
\hline Hsu [84] & 74 & $\begin{array}{l}\text { Nasopharyngeal } \\
\text { carcinoma }\end{array}$ & $\begin{array}{l}\text { FFPE tissues/IHC }(46 \\
\text { samples) }\end{array}$ & NA & $\begin{array}{l}\text { Goat polyclonal antibody anti-human } \\
\text { PD-1 (R\&D Systems, Minneapolis) }\end{array}$ \\
Correlation:
\end{tabular}

Snap-frozen tissue (28

Correlation

samples)

PD- $1+-$ CD8 expression/DFS $(P=0.007)$.

PD-1 + CD8 expression/locoregional

recurrence free Survival $(P=0.004)$.

PD-1 +-CD8

expression/locoregional recurrence-free survival (four groups) $(P=0.004)$.

High PD-1 +-CD8 group had a 6.5 times

higher risk of locoregional recurrence

$(P=0.005)$, a 6.5 times higher risk of

treatment

failure ( $P=0.013)$, and a 9.5 times higher

risk of death $(P=0.015)$;

PD-1 expression

in intratumoral CD8 cells: independent

effect on the post-treatment outcome

$\mathrm{NO} \rightarrow$

No Correlation:

PD1 +-CD8 expression/distant

metastasis-free survival $(P=0.31)$.

PD-1 +-CD4 expression/

OS $(P=0.56)$.

PD-1 +-CD4 expression/

DFS $(P=0.90)$ 


\begin{tabular}{|c|c|c|c|c|c|c|}
\hline Author & $\mathrm{N}^{\circ}$ & Tumor & $\begin{array}{l}\text { Tissues/detection } \\
\text { method }\end{array}$ & $\begin{array}{l}\text { Cell } \\
\text { immunolocalization/cut- } \\
\text { off for } \\
\text { positivity }\end{array}$ & & Prognostic role \\
\hline Wahlin [86] & 70 & Follicular lymphoma & $\begin{array}{l}\text { FFPE tissues/IHC } \\
\text { Tissue microarray } \\
\text { (TMA) }\end{array}$ & $\begin{array}{l}\text { Non-nuclear } \\
\text { Quantification: cell } \\
\text { count }=\text { PD-1 positive } \\
\text { cells/sum of total } \\
\text { cellular area } \\
\text { Compartment: } \\
\text { total/follicular/interfollic }\end{array}$ & $\begin{array}{l}\text { Anti-PD-1 Ab non-specified } \\
\text { cular }\end{array}$ & $\begin{array}{l}\text { YES } \rightarrow \\
\text { Correlation } \\
\text { Follicular PD1 positivity/ } \\
\text { favorable prognosis }(\mathrm{RR}=0.34, P=0.01) \\
\text { along with interfollicular } \mathrm{CD} 8+\text { cells } \\
(\mathrm{RR}=0.86, P=0.014) \text { independent of FLIPI }\end{array}$ \\
\hline Takahashi [87] & $\begin{array}{l}82 \text { (patients treated by } \\
\text { standard R-CHOP as } \\
\text { initial therapy) }\end{array}$ & Follicular lymphoma & $\mathrm{NA}$ & $\begin{array}{l}\text { NA } \\
\text { PD-1 positivity } \\
\text { staining: }>14.4 \%\end{array}$ & $\begin{array}{l}\text { Anti-PD1 } \\
\text { MoAb } \\
\text { (Abcam 52587) }\end{array}$ & $\begin{array}{l}\mathrm{NO} \rightarrow \\
\text { No correlation } \\
\text { CR rate/PD-1 positivity patients } \\
\text { No correlation PD-1 positive cells } \\
(\geq 7.5 \%) / \mathrm{PFS}(P=0.20) \\
\text { No correlation PD-1 positive cells } \\
(\geq 7.5 \%) / \mathrm{OS}(P=0.60) \\
\text { PD-1 is not a Independent prognostic factor } \\
\text { Among male patients }(n=43) \text { : correlation } \\
\text { PD-1 positive cells/worse PFS }(P=0.03)\end{array}$ \\
\hline Richendollar [88] & 91 & Follicular lymphoma & $\begin{array}{l}\text { Tissue microarray } \\
\text { (TMA)/IHC }\end{array}$ & $\begin{array}{l}\text { NA } \\
\text { PD-1 positivity: } \\
\text { >35.6 PD-1 positivity } \\
\text { cells/HPF }\end{array}$ & $\begin{array}{l}\text { Anti-PD1 } \\
\text { Polyclonal (Abcam) }\end{array}$ & $\begin{array}{l}\text { YES } \\
\text { Association } \\
\text { PD1 positivity T cells/decreased OS1 } \\
(\mathrm{HR}=1.64, P=0.10) \\
\text { PD1: independent prognostic factor for } \\
\text { decreased OS }\end{array}$ \\
\hline Muenst [89] & 189 & Hodgkin lymphoma & $\begin{array}{l}\text { Tissue microarray } \\
\text { (TMA)/IHC }\end{array}$ & $\begin{array}{l}\text { NA } \\
\text { PD-1 positivity: } \\
\text { >23 PD-1 positivity } \\
\text { cells/mm2 }\end{array}$ & $\begin{array}{l}\text { Anti-PD-1 Goat antihuman MoAb } \\
\text { (AF1086 R\&D Systems) }\end{array}$ & $\begin{array}{l}\text { YES } \rightarrow \\
\text { PD1 positivity T cells/worse OS } \\
(P=0.005) \\
\mathrm{NO} \rightarrow \\
\mathrm{PD} 1 \text { is not a Independent prognostic factor } \\
(P=0.022)\end{array}$ \\
\hline
\end{tabular}




\begin{tabular}{|c|c|c|c|c|c|c|}
\hline Shi [90] & 56 & $\begin{array}{l}\text { Hepatocellular } \\
\text { carcinoma }\end{array}$ & $\begin{array}{l}\text { FFPE tissues/IHC, } \\
\text { FACS }\end{array}$ & $\begin{array}{l}\text { Both } \\
\text { cell-surface } \\
\text { membrane and } \\
\text { cytoplasm area }\end{array}$ & $\begin{array}{l}\text { Anti-PD1 } \\
\text { Mouse antihuman MoAb (R\&D } \\
\text { Systems) } \\
\text { Anti-PD-L1 } \\
\text { Mouse antihuman MoAb } \\
\text { (Biolegend), FACS with } \\
\text { PE-conjugated PD-1 and PD-L1 } \\
\text { (eBiosciences) }\end{array}$ & $\begin{array}{l}\text { YES } \rightarrow \\
\text { Correlation } \\
\text { High levels of intratumoral PD1 }+ \text { CD } 8+\mathrm{T} \\
\text { cells/ } \\
\text { shorter DFS } \\
(P<0.001)\end{array}$ \\
\hline Zeng [83] & $\begin{array}{l}109 \text { (cryoablation) } \\
23 \text { (IHC) }\end{array}$ & $\begin{array}{l}\text { HBV-related } \\
\text { Hepatocellular } \\
\text { carcinoma }\end{array}$ & FFPE tissues/IHC & NA & NA & $\begin{array}{l}\text { YES } \\
\text { Correlation } \\
\text { PD-1/TFS }(P \leq 0.001) \\
\text { PD-1/OS }(P=0.001) \\
\text { Circulating PD-1 expression }=\text { independent } \\
\text { poor prognostic factor for TFS }(P=0.046)\end{array}$ \\
\hline
\end{tabular}

\author{
antibody.
}


Gadiot and colleagues evaluated paraffin-embedded tissues of 63 patients with stages III-IV melanoma diagnosed by the Netherlands Cancer Institute between 2000 and 2004. PDL1 was analyzed in benign nevi $(n=10)$, primary melanomas $(n=43)$, satellite metastases $(n=8)$, in transit-metastases $(n=21)$, and distant organ metastases $(n=22)$. Interestingly, the authors showed that $20 \%$ of the benign nevi samples were PD-L1-positive, while only $5 \%$ of primary melanomas were PD-L1 positive. Satellite metastases, in-transit metastases, lymph nodes and distant metastases were PD-L1 positive in $25 \%, 40 \%, 14 \%$, and $18 \%$ of cases, respectively. PD-L1 was more expressed in satellite and in-transit metastases compared with lymph node, and distant metastases. In this study, PD-L1 did not correlate with disease free or overall survival [65].

Finally, Taube et al. demonstrated a correlation between PD-L1 and the presence of TILs in both nevi and malignant melanoma: $98 \%$ of PD-L1 positive melanomas were associated with TILs compared with only $28 \%$ of PD-L1 negative melanomas. Furthermore, PD-L1 positive melanocytes were almost always localized adjacent to TILs. Interestingly, a positive correlation between surface PD-L1 expression by tumor cells $(\geq 5 \%)$ and overall survival in metastatic disease in 56 patients was reported. On the other hand, there was no significant difference in survival in relation to PD-L1 expression in primary melanoma [66].

There are important differences in the first two above referenced studies [47,65]. PD-L1 was evaluated with different immunostaining protocols. In Hino's study, it is unclear whether the authors tested their antibodies against isotype controls and PD-L1Fc protein blockade to ensure lack of background or unspecific signals.

Another likely explanation for the conflicting results could be that small series of fewer than 100 melanoma patients from diverse origin were analyzed. The most noticeable difference between the Asian melanoma patient population [47] and the cohort population evaluated by Gadiot is the tumor type. In the latter, superficial spreading and nodular melanomas were predominantly diagnosed, whereas in the cohort of Hino et al., mainly patients with acral lentiginous melanomas were included. The latter have been shown to preferentially express c-kit amplifications or mutations, whereas the melanomas from the European cohort are more likely to express BRAF mutations. Finally, more women were included in Hino's study. Women are known to have a better prognosis in melanoma and may have influenced the prognostic analysis of PD-L1.

Finally, Taube et al. suggest that patients with both PDL1 expression and TILs in melanoma may have improved prognosis compared with the group with PD-L1 expression without TILs [66]. This study seems to suggest that the evaluation of PD-L1 expression is important but not sufficient to understand the intricate interplay between melanoma and the immune system. PD-L1 overexpression in melanoma with TILS could be suggestive of an active and efficient immune response, and therefore may correlate with a better prognosis.

\section{Clinical trials and future developments}

We performed an extensive "Medline" and Cancerlit literature review (1995-2013). Various combinations of search terms were used depending on the requirements of the database being searched. These terms included "PD1" or "PD-L1" or "B7-H1", in combination with "cancer patients" or "melanoma" or "tumor" or "tumour" or "activity" or "safety" or "phase 1" or "immunotherapy" or "immune checkpoints" or "lymphocytes" or "randomized" or "prospective" or "clinical" or "early phase" or "nivolumab" or "lambrolizumab". In addition, relevant references in each article were scanned, and we did manual searches of abstracts from the annual meetings of the American Society of Hematology (1993-2012), American Society for Clinical Oncology (1993-2013), European Haematology Association (1993-2012), and European Society for Medical Oncology (1998-2013).

Table 4 summarizes the main prospective phase 1 studies evaluating anti PD-1/PD-L1 antibodies in cancer patients. Topalian and coll. enrolled 296 patients with advanced melanoma, non-small-cell lung cancer, castrationresistant prostate cancer, or renal-cell or colorectal cancer to receive BMS-936558 (anti-PD-1 antibody) at a dose of $0.1-10.0 \mathrm{mg} / \mathrm{kg}$ of body weight every 2 weeks for 8 week-treatment cycles for 12 cycles until progression or complete response [67]. Common treatment-related adverse events included fatigue, rash, diarrhea, pruritus, decreased appetite, and nausea. Grade 3 or 4 drug-related toxicities occurred in $14 \%$ of patients; moreover, there were three deaths from pulmonary toxicity. Drug-related serious adverse events occurred in 32 of 296 patients (11\%). The spectrum, frequency, and severity of treatment related adverse events were generally similar across the dose levels tested. Drug-related adverse events of special interest (e.g., those with potential immune-related causes) included pneumonitis, vitiligo, colitis, hepatitis, hypophysitis, and thyroiditis. In this trial, objective responses were observed in $28 \%$ of melanoma patients. Interestingly, partial sustained, long term responses were observed at each cohort level $(0.3-10 \mathrm{mg} / \mathrm{kg})$. At a dose of $3.0 \mathrm{mg} / \mathrm{kg}$, objective responses were noted in 7 of 17 patients (41\%). As measured by standard RECIST criteria, objective responses were long lasting, with response durations of 1 year or more in 13 out of 26 patients who had a response with 1 year or more of follow-up.

In the same study immunohistochemical analysis was performed on pretreatment tumor specimens obtained from 42 patients. Objective response was reported in a subgroup of patients (9/25 patients: 36\%) with PD-L1-positive tumors. These preliminary data would suggest a relationship between PD-L1 expression on tumor cells and objective response.

Hodi et al. reported the activity and safety of BMS-936558 in patients with previously treated advanced melanoma [68]. BMS-936558 was administered every two weeks at doses of $0.1-10 \mathrm{mg} / \mathrm{kg}$ during dose-escalation and/or cohort expansion. Patients received up to 12 cycles ( 4 doses/cycle) of 
Table 4

Main prospective phase 1 studies evaluating anti PD-1/PD-L1 antibodies in cancer patients.

\begin{tabular}{|c|c|c|c|c|c|c|c|}
\hline Author & Tumors & Drug & Dose/schedule (i.v.) & Pts $(n)$ & OR $(\%)$ & PFS & OS \\
\hline \multicolumn{8}{|c|}{ Anti PD-1 antibody } \\
\hline \multirow[t]{6}{*}{ Topalian [67] } & Melanoma & BMS936558 & $0.1 \mathrm{mg} / \mathrm{kg}$ & 296 & - & $\underline{\text { At } 24 \text { weeks }}$ & NR \\
\hline & NSCLC & & $0.3 \mathrm{mg} / \mathrm{kg}$ & & $6 \%$ & & \\
\hline & CRPC & & $1.0 \mathrm{mg} / \mathrm{kg}$ & & $32 \%$ & $47 \%$ & \\
\hline & $\mathrm{RCC}$ & & $3 \mathrm{mg} / \mathrm{kg}$ & & $18 \%$ & $67 \%$ & \\
\hline & CRC & & $10 \mathrm{mg} / \mathrm{kg}$ & & & $56 \%$ & \\
\hline & & & Every 2 weeks & & & & \\
\hline \multirow[t]{5}{*}{ Brahmer [91] } & Melanoma & MDX1106 & $0.3 \mathrm{mg} / \mathrm{kg}$ & 39 & 0 & NR & \\
\hline & NSCLC & & $1.0 \mathrm{mg} / \mathrm{kg}$ & & 0 & & \\
\hline & CRPC & & $3 \mathrm{mg} / \mathrm{kg}$ & & $17 \%$ & & \\
\hline & $\mathrm{RCC}$ & & $10 \mathrm{mg} / \mathrm{kg}$ & & $10 \%$ & & \\
\hline & $\mathrm{CRC}$ & & & & & & \\
\hline \multirow[t]{5}{*}{ Berger [92] } & Advanced & CT-011 & $0.2 \mathrm{mg} / \mathrm{kg}$ & $17 *$ & & NR & At 21 days \\
\hline & Hematologic & & $0.6 \mathrm{mg} / \mathrm{kg}$ & & & & \\
\hline & malignancies & & $1.5 \mathrm{mg} / \mathrm{kg}$ & & $6 \%$ & & $76 \%$ \\
\hline & & & $3 \mathrm{mg} / \mathrm{kg}$ & & & & \\
\hline & & & $6 \mathrm{mg} / \mathrm{kg}$ & & & & \\
\hline \multirow[t]{4}{*}{ McDermott [93] } & $\mathrm{RCC}$ & BMS936558 & & 34 & & $\underline{\text { At } 24 \text { weeks }}$ & NR \\
\hline & & & $1.0 \mathrm{mg} / \mathrm{kg}$ & & $28 \%$ & $50 \%$ & \\
\hline & & & $10 \mathrm{mg} / \mathrm{kg}$ & & $31 \%$ & $67 \%$ & \\
\hline & & & Every 2 weeks & & & & \\
\hline \multirow[t]{5}{*}{ Patnaik [94] } & Melanoma & MK3475 & & 9 & & & \\
\hline & NSCLC & & $1.0 \mathrm{mg} / \mathrm{kg}$ & & & & \\
\hline & $\mathrm{RC}$ & & $3 \mathrm{mg} / \mathrm{kg}$ & & NR & NR & NR \\
\hline & Sarcoma & & $10 \mathrm{mg} / \mathrm{kg}$ & & & & \\
\hline & Carcinoid & & Every 2 weeks & & & & \\
\hline \multirow[t]{4}{*}{ Kudchadkar [95] } & Melanoma & BMS936558 & $1.0 \mathrm{mg} / \mathrm{kg}$ & 30 & & & \\
\hline & & Plus vaccines\# & $3 \mathrm{mg} / \mathrm{kg}$ & & NR & NR & NR \\
\hline & & & $10 \mathrm{mg} / \mathrm{kg}$ & & & & \\
\hline & & & Every 2 weeks & & & & \\
\hline \multirow[t]{6}{*}{ Hodi [68] } & Melanoma & BMS936558 & $0.1 \mathrm{mg} / \mathrm{kg}$ & 95 & $20 \%$ & & \\
\hline & & & $0.3 \mathrm{mg} / \mathrm{kg}$ & & $20 \%$ & & \\
\hline & & & $1.0 \mathrm{mg} / \mathrm{kg}$ & & $29 \%$ & NR & NR \\
\hline & & & $3 \mathrm{mg} / \mathrm{kg}$ & & $41 \%$ & & \\
\hline & & & $10 \mathrm{mg} / \mathrm{kg}$ & & $20 \%$ & & \\
\hline & & & Every 2 weeks & & & & \\
\hline \multirow[t]{4}{*}{ Brahmer [96] } & NSCLC & BMS936558 & $1.0 \mathrm{mg} / \mathrm{kg}$ & 75 & $6 \%$ & NR & NR \\
\hline & & & $3 \mathrm{mg} / \mathrm{kg}$ & & $28 \%$ & & \\
\hline & & & $10 \mathrm{mg} / \mathrm{kg}$ & & $19 \%$ & & \\
\hline & & & Every 2 weeks & & & & \\
\hline \multicolumn{8}{|c|}{ Anti PD-L1 antibody } \\
\hline \multirow[t]{7}{*}{ Brahmer [70] } & Melanoma & & & 160 & & At 24 weeks & \\
\hline & NSCLC & & $0.3 \mathrm{mg} / \mathrm{kg}$ & & 0 & $42 \%$ & \\
\hline & CRPC & BMS936559 & $1.0 \mathrm{mg} / \mathrm{kg}$ & & $6 \%$ & $31 \% \bullet$ & NR \\
\hline & $\mathrm{RCC}$ & & $3 \mathrm{mg} / \mathrm{kg}$ & & $29 \%$ & $22 \% \infty$ & \\
\hline & CRC & & $10 \mathrm{mg} / \mathrm{kg}$ & & $19 \%$ & & \\
\hline & $\mathrm{OC}$ & & & & & $N R$ & \\
\hline & $\mathrm{PC}$ & & & & & & \\
\hline \multirow[t]{6}{*}{ Tykodi [97] } & Melanoma & BMS936559 & & 162 & & & \\
\hline & NSCLC & & $0.3 \mathrm{mg} / \mathrm{kg}$ & & & & \\
\hline & $\mathrm{OC}$ & & $1.0 \mathrm{mg} / \mathrm{kg}$ & & $10 \%$ & NR & NR \\
\hline & $\mathrm{PC}$ & & $3 \mathrm{mg} / \mathrm{kg}$ & & & & \\
\hline & $\mathrm{RCC}$ & & $10 \mathrm{mg} / \mathrm{kg}$ & & & & \\
\hline & $\mathrm{CRC}$ & & Every 2 weeks & & & & \\
\hline
\end{tabular}

NSCLC, non-small cell lung cancer; CPRC, castration-resistant prostate cancer; RCC, renal cell carcinoma; CRC, colorectal cancer; OC, ovarian cancer; PC, pancreatic cancer; $\mathrm{RC}$ : rectal cancer.

\# MART-1/gp100/NY-ESO-1 peptides with adjuvant Montanide ISA 51.

* 8 out of 17 patients: acute leukemia.

$\circ$ : Melanoma patients.

•: NSCLC.

$\infty$ : ovarian cancer.

NR: not reported.

$N$ : number. 
Table 5

Ongoing clinical trials evaluating anti PD-L1 in cancer patients.

Monotherapy

Non-randomized

\begin{tabular}{|c|c|c|c|c|}
\hline Drug & Phase & Trial & Disease & Primary outcome measures \\
\hline MPDL3280A & 1 & NCT01375842 & $\begin{array}{l}\text { Solid tumors or hematologic } \\
\text { malignancies }\end{array}$ & - DLTs \\
\hline \multirow[t]{4}{*}{ BMS-936559 } & 1 & NCT01452334 & Non-Hodgkin’s lymphoma & $\begin{array}{l}\text { - Safety } \\
\text { - Tolerability }\end{array}$ \\
\hline & & & Hodgkin lymphoma & \\
\hline & & & Multiple myeloma chronic & \\
\hline & & & Myelogenous leukemia & \\
\hline MPDL3280A & 2 & NCT01846416 & PD-L1-positive NSCLC & - OR \\
\hline BMS-936559 & 1 & NCT00729664 & Solid tumors & $\begin{array}{l}\text { - Safety } \\
\text { - MTD } \\
\text { - DLT }\end{array}$ \\
\hline BMS-936559 & 1 & NCT01455103 & Melanoma & - Immunomodulatory effects \\
\hline \multicolumn{5}{|c|}{$\begin{array}{l}\text { Combination therapy } \\
\text { Non-randomized }\end{array}$} \\
\hline $\begin{array}{l}\text { - MPDL3280A } \\
\text { - Vemurafenib }\end{array}$ & 1 & NCT01656642 & Melanoma & $\begin{array}{l}\text { - Incidence of DLTs } \\
\text { - Nature of DLTs } \\
\text { - Incidence, nature or severity } \\
\text { of adverse events and } \\
\text { laboratory abnormalities }\end{array}$ \\
\hline $\begin{array}{l}\text { - MPDL3280A } \\
\text { - Bevacizumab } \\
\text { - Chemotherapy }\end{array}$ & 1 & NCT01633970 & Advanced solid tumors & $\begin{array}{l}\text { - Safety } \\
\text { - DLTs/MTD }\end{array}$ \\
\hline
\end{tabular}

DLT, dose limiting toxicity; NSCLC, non-small cell lung cancer; OR, objective response; MTD, maximum tolerated dose.

treatment or until PD or CR. Ninety-five melanoma patients with Eastern Cooperative Oncology Group (ECOG) Performance Status (PS) $\leq 2$ were treated with BMS-936558 at $0.1(n=13), 0.3(n=17), 1 \quad(n=28), 3(n=17)$, or $10 \mathrm{mg} / \mathrm{kg}$ $(n=20)$. The majority of patients $(60 / 95)$ had received interferon-alpha or IL-2 (prior anti-CTLA-4 excluded). Seven out of 95 patients previously received B-raf inhibitor therapy. Sixty out of 95 patients had previously received more than 2 lines of treatment. The incidence of grade 3-4 related adverse events (Aes) was 19\% and included gastrointestinal (4\%), endocrine (2\%), and hepatobiliary disorders (1\%). There were no drug-related deaths. Clinical activity was observed at all dose levels, including patients with visceral or bone metastases. Of 20 patients with objective response, 12 had object response duration $\geq 1$ year, and 6 patients were on study with objective response duration between 1.9 and 11.3 months. Several patients had prolonged stable disease.

Recently Hamid et al. evaluated the anti-PD-1 antibody lambrolizumab at a dose of $10 \mathrm{mg} / \mathrm{kg}$ of body weight every 2 or 3 weeks or $2 \mathrm{mg} / \mathrm{kg}$ every 3 weeks in 135 patients with advanced melanoma [69].

The confirmed response rate across all dose cohorts was $38 \%$, with the highest confirmed response rate, $52 \%$, observed in the cohort that received $10 \mathrm{mg} / \mathrm{kg}$ every 2 weeks. The response rate did not differ significantly between patients pretreated or not with ipilimumab. At a median follow-up of 11 months, among patients achieving a response to treatment, long term responses were reported in $81 \%$ of patients.
The overall median progression-free survival among the 135 patients was longer than 7 months. Common adverse events treatment-related were fatigue, rash, pruritus, and diarrhea; most of the adverse events were low grade.

Finally, Brahmer et al. evaluated 207 patients (75 with non-small cell lung cancer, 55 with melanoma, 18 with colorectal cancer, 7 with gastric cancer, and 4 with breast cancer), using anti-PD-L1 antibody (BMS-936559) in a multicenter Phase I trial at multiple escalating dose (from 0.3 to $10 \mathrm{mg} / \mathrm{kg}$ ) [70]. Anti-PD-L1 antibody was administered every 14 days in 6-week cycles, for up to 16 cycles or until the patient had a complete response or confirmed disease progression. Grades 3-4 immune-related toxic effects occurred in $9 \%$ of patients. An objective response, complete or partial, was observed in $9 / 52$ patients with melanoma (29\% response rates at $3 \mathrm{mg} / \mathrm{kg}$ ), 2/17 with renal cell cancer, $5 / 49$ with nonsmall cell lung cancer (mostly non-squamous subgroup) and 1/17 with ovarian cancer. Prolonged stabilization of disease was observed for $12-41 \%$ lasting at 24 weeks [70].

Overall, with anti PD-1 or anti PD-L1 antibodies, the incidence of serious (grade 3-4) adverse effects was at a range similar to that with CTLA-4-blocking antibodies, but most were less clinically significant with the exception of pneumonitis, which led to death as a result of toxicity. Blocking the ligand PD-L1 with the fully human IgG4 antibody BMS936559 resulted in a slightly lower frequency of objective tumor responses and also fewer adverse effects in phase I testing. These initial experiences, together with the current initial 
Table 6

Ongoing clinical trials with anti-pd-1 antibodies.

Monotherapy

Non-randomized

\begin{tabular}{|c|c|c|c|c|}
\hline Drug & Phase & Trial & Disease & Primary outcome measures \\
\hline BMS-936558 & 1 & NCT01621490 & Melanoma & - Immunomodulatory effects \\
\hline BMS-936558 & 1 & NCT01592370 & $\begin{array}{l}\text { - Non-Hodgkin’s lymphoma } \\
\text { - Hodgkin lymphoma } \\
\text { - Multiple myeloma } \\
\text { - CML }\end{array}$ & $\begin{array}{l}\text { - Safety and } \\
\text { - Tolerability }\end{array}$ \\
\hline BMS-936558 & 2 & NCT01721759 & NSCLC & - OR \\
\hline BMS-936558 & 1 & NCT01658878 & $\mathrm{HCC}$ & - Safety \\
\hline BMS-936558 & 1 & NCT00836888 & Solid tumors & $\begin{array}{l}\text { - Safety } \\
\text { - Pharmacokinetic }\end{array}$ \\
\hline AMP-224 & 1 & NCT01352884 & Solid tumors & $\begin{array}{l}\text { - Safety } \\
\text { - Pharmacokinetic } \\
\text { - Tolerability }\end{array}$ \\
\hline Randomized & & & & \\
\hline $\begin{array}{l}\text { BMS-936558 } 0.3 \mathrm{mg} / \mathrm{kg} \\
\text { versus } \\
\text { BMS-936558 } 2 \mathrm{mg} / \mathrm{kg} \\
\text { versus } \\
\begin{array}{l}\text { BMS-936558 } 10 \mathrm{mg} / \mathrm{kg} \\
\text { (pretreated patients) }\end{array} \\
\begin{array}{l}\text { versus } \\
\text { BMS-936558 } 10 \mathrm{mg} / \mathrm{kg} \\
\text { (naïve patients) }\end{array}\end{array}$ & 1 & NCT01358721 & $\mathrm{RCC}$ & - Immunomodulatory activity \\
\hline BMS-936558 & 3 & NCT01721772 & Melanoma & $-\mathrm{OS}$ \\
\hline
\end{tabular}

versus

Dacarbazine

MK-3475

NCT01721772

at different dose levels:

Low $(0.1 \mathrm{mg} / \mathrm{kg})$

Intermediate $(3 \mathrm{mg} / \mathrm{kg})$

High $(10 \mathrm{mg} / \mathrm{kg})$

Patients with Melanoma and

NSCLC will be randomized to:

Low dose

versus

Intermediate dose

versus

High dose
- MK-3475

versus

- Carboplatin or

- Carboplatin +

- Paclitaxel

- Paclitaxel or

- Dacarbazine or

- BMS-936558
- Temozolomide
NCT01295827

NCT01704287

NCT01673867
Any type of carcinoma or

Melanoma or NSCLC

Melanoma and NSCLC

Melanoma

- OR

- PFS

- OS

versus

- Docetaxel 
Table 6 (Continued)

Monotherapy

Non-randomized

\begin{tabular}{|c|c|c|c|c|}
\hline Drug & Phase & Trial & Disease & Primary outcome measures \\
\hline - BMS-936558 & 3 & NCT01642004 & Squamous cell NSCLC & - OR \\
\hline versus & & & & - OS \\
\hline \multicolumn{5}{|l|}{ - Docetaxel } \\
\hline - BMS-936558 & 3 & NCT01721746 & Melanoma & - OR \\
\hline versus & & & & - OS \\
\hline \multicolumn{5}{|c|}{$\begin{array}{l}\text { - Carboplatin or } \\
\text { - Paclitaxel }\end{array}$} \\
\hline - BMS-936558 & 3 & NCT01721772 & Melanoma & - OS \\
\hline \multicolumn{5}{|l|}{ versus } \\
\hline \multicolumn{5}{|l|}{ - Dacarbazine } \\
\hline - BMS-936558 & 3 & NCT01668784 & $\mathrm{RCC}$ & - OS \\
\hline
\end{tabular}

versus

- Everolimus

Combination therapy

Non-randomized

- BMS-936558

- NY-ESO-1

(peptide vaccine)

- gp100: 280-288

(peptide vaccine)

- BMS-936558

- MART-1

(peptide vaccine)

- NY-ESO-1

(peptide vaccine)

- gp100: 209-217(210 M)

(peptide vaccine)

- gp100: 280-288(288V)

(peptide vaccine)

\section{- BMS-936558 \\ - BMS-986015 \\ (ANTI-KIR):}

- BMS-936558

- Gemcitabine

- BMS-982470

(Recombinant Interleukin-21,

rIL-21)

- BMS-936558

\footnotetext{
- BMS-936558

$\pm$

- DC RCC vaccine

- BMS-936558

$\pm$

- DC AML vaccine

- BMS-936558
}

- DC fusion vaccine
NCT01176474

Melanoma

Melanoma

- OR
- Time to relapse in patients with resected Stage IIIC/IV melanoma
-NSCLC

-Melanoma, -RCC

-Colorectal cancer

-Ovarian cancer

Pancreatic cancer

Any type of carcinoma
- Safety and

- Tolerability

- Feasibility and

- Safety

- Safety
NCT01629758
NCT01313416
RCC

AML

Multiple myeloma
- Safety

- OR

- Toxicity 
Table 6 (Continued)

\begin{tabular}{|c|c|c|c|c|}
\hline \multicolumn{5}{|l|}{$\begin{array}{l}\text { Monotherapy } \\
\text { Non-randomized }\end{array}$} \\
\hline Drug & Phase & Trial & Disease & Primary outcome measures \\
\hline $\begin{array}{l}\text { - BMS-936558 } \\
\text { - BMS-986015 } \\
\text { (ANTI-KIR) }\end{array}$ & 1 & NCT01714739 & Solid Tumors & $\begin{array}{l}\text { - Safety } \\
\text { - Tolerability }\end{array}$ \\
\hline Randomized & & & & \\
\hline 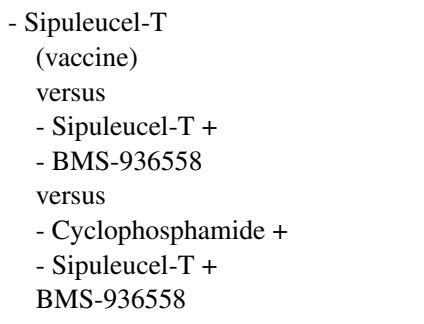 & 2 & NCT01420965 & Prostate cancer & $\begin{array}{l}\text { - Feasibility } \\
\text { - Immune efficacy }\end{array}$ \\
\hline $\begin{array}{l}\text { - BMS-936558 or } \\
\text { - BMS-936558 Plus - Ipilimumab }\end{array}$ & 3 & NCT01844505 & Melanoma & - OS \\
\hline versus & & & & \\
\hline Ipilimumab alone & & & & \\
\hline
\end{tabular}

NSCLC, non-small cell lung cancer; HCC, hepatocellular carcinoma; RCC, renal cell carcinoma; CML, chronic myelogenous leukemia; AML, acute myelogenous leukemia; DC, dendritic cell; KIR, killer-cell immunoglobulin-like receptor; RR, response rate; PFS, progression free survival; OS, overall survival; OR, overall response.

clinical testing of a series of other antibodies and blocking constructs to the PD-1/PD-L1 axis, provide an impetus for the continued clinical testing of these highly active immunotherapies for melanoma.

Tables 5 and 6 summarize ongoing clinical trials with anti PD-1 or anti PD-L1 antibodies.

Based on experimental data, blockade of B7-H1 or PD-1 is not expected to stimulate de novo immune responses but rather to enhance ongoing immune responses against tumor antigens, since this axis is implicated in the effective phase and not in the priming phase of the immune response. A combinational strategy to elicit the immune response could improve the objective response rate as well as the duration of response. In patients with advanced disease it is likely that the majority of TILs have an "exhausted" phenotype. The presence of inhibitory molecules would render these cells insensitive to the action of anti-PD-1. On the basis of these considerations, preliminary results in mice models suggest that combination therapies may be helpful in restoring an activating phenotype in the tumor microenvironment [71]. In experimental models combining B7-H1/PD-1 blockade with cancer vaccines [72-75], adoptive transfer of preactivated $\mathrm{T}$ cells, or T cell stimulation with anti-CD137 [76] often provides dramatic synergistic antitumor effects, in some cases eradicating well-established tumors.

Furthermore there is preclinical evidence that CTLA-4 and PD-1 could play complementary roles in regulating adaptive immunity. Curran et al. reported, in mice xenograft, that the combination of CTLA-4 and PD-1 blockade determines the accumulation of CTLA-4/PD-1 double-positive $\mathrm{T}$ effector cells within B16 melanoma cell lines [77]. These data suggest that $T$ cells that would otherwise be functionally and proliferatively repressed are instead able to continue expanding and carrying out effector functions.

In the same model the combination of CTLA-4 and PD-1 blockade resulted more than twice as effective as either alone in promoting the rejection of B16 melanoma cell lines. Interestingly the further addition of PD-L1 antibody elevates the rate of tumor-free survival to $65 \%$ versus $10 \%$ with CTLA-4 blockade alone [77].

Recently, on the basis of these observations, a phase 1 study to investigate the safety and efficacy of combined CTLA-4 and PD-1 blockade [with the use of ipilimumab (anti-CTLA4 antibody) and nivolumab (anti-PD-1 antibody), respectively] in patients with advanced melanoma has been conducted [78]. In this study the objective-response rate for all patients in the concurrent-regimen group was $40 \%$. At the maximum tolerated doses (nivolumab at a dose of $1 \mathrm{mg} / \mathrm{kg}$ of body weight and ipilimumab at a dose of $3 \mathrm{mg} / \mathrm{kg}$ ), $53 \%$ of patients had an objective response, all with tumor reduction of $80 \%$ or more. Grade 3 or 4 toxicities occurred in $53 \%$ of patients and were generally reversible and qualitatively similar to those reported with monotherapy (ipilimumab or nivolumab alone). 


\section{Conclusion}

The past decade has seen important strides in the field of melanoma research. Extensive research over the past twenty years yielded the identification of new and innovative ways to manipulate the immune response to cancer. Negative regulators of the immune system, called immunologic checkpoints, have been found to play important roles in restraining otherwise effective anti-tumor immunologic responses. Therapies that target the PD-1/PD-L1 axis have demonstrated promising clinical results. Treatment is generally well tolerated, but a novel spectrum of side effects, termed immune-related adverse events, has been experienced. Unfortunately, not all patients respond to these therapies, and evaluation of biomarkers predictive of response is ongoing.

Some open issues and scarce information may unfavorably impact the management of patients with advanced melanoma, therefore, priority actions are needed in this direction. In particular:

1. A standardized methodology to define the PD1/PD-L1 positive melanoma is strongly needed. Tumor heterogeneity in terms of PD-L1 expression, variability in the assays and cell immunolocalization as well as cut-off values for positive versus negative PDL-1 immunohistochemical expression are not uniformly defined and do not currently allow appropriate patient's classification.

2. The prognostic and predictive role of TILS (overall estimation and/or immunophenotyping) in addition to PD1/PD-L1 remains to be determined in order to better stratify patients and to identify those who may benefit from therapies that target PD-1/PD-L1 axis.

3. The anti PD-1 and PD-L1 antibodies have demonstrated clinical activity in early clinical trials, but randomized studies with immune correlates are lacking so far.

4. Combinations of PD-L1/PD-1 blockade with cancer vaccines, adoptive transfer of pre-activated $\mathrm{T}$ cells, $\mathrm{T}$ cell stimulation with anti-CD137 or MAPK inhibitors should be investigated as they could provide synergistic antitumor effects.

\section{Reviewers}

Piotr Rutkowski, MD, PhD, Professor; Head of Department, Maria Sklodowska-Curie Memorial Cancer Center - Institute, Department of Soft Tissue/Bone Sarcoma and Melanoma, Roentgena Str. 5, PL-02-781 Warsaw, Poland.

Nitin Chakravarti, PhD, Instructor, Department of Pathology - Research, Division of Pathology/Lab Medicine, The University of Texas MD Anderson Cancer Center, Houston, TX, The University of Texas MD Anderson Cancer Center, 1515 Holcombe Blvd., Houston, TX 77030, USA.

Olivier Michielin, MD, PhD, Professor, UNIL, Department of Oncology, Experimental Oncology Unit, CHUV, Rue du Bugnon 46, CH-1011 Lausanne, Switzerland.

\section{Conflict of interest statement}

The authors declare that there is no conflict of interest.

\section{References}

[1] Suvà ML, Riggi N, Bernstein BE. Epigenetic reprogramming in cancer. Science 2013;339:1567-70.

[2] Hanahan D, Weinberg RA. The hallmarks of cancer. Cell 2000;100:57-70.

[3] Hanahan D, Weinberg RA. Hallmarks of cancer: the next generation. Cell 2011;144:646-74.

[4] Hoenicke L, Zender L. Immune surveillance of senescent cells: biological significance in cancer- and non-cancer pathologies. Carcinogenesis 2012;33:1123-6.

[5] Miska J, Bas E, Devarajan P, Chen Z. Autoimmunity-mediated antitumor immunity: tumor as an immunoprivileged self. Eur J Immunol 2012;42:2584-96.

[6] Klein G, Klein E. Surveillance against tumors: is it mainly immunological? Immunol Lett 2005;100:29-33.

[7] Legha SS, Ring S, Bedikian A, et al. Treatment of metastatic melanoma with combined chemotherapy containing cisplatin, vinblastine and dacarbazine (CVD) and biotherapy using interleukin-2 and interferonalpha. Ann Oncol 1996;7:827-35.

[8] Legha SS, Ring S, Eton O, et al. Development of a biochemotherapy regimen with concurrent administration of cisplatin, vinblastine, dacarbazine, interferon alfa, and interleukin-2 for patients with metastatic melanoma. J Clin Oncol 1998;16:1752-9.

[9] O'Day SJ, Boasberg PD, Piro L, et al. Maintenance biotherapy for metastatic melanoma with interleukin-2 and granulocyte macrophage-colony stimulating factor improves survival for patients responding to induction concurrent biochemotherapy. Clin Cancer Res 2002;8:2775-81.

[10] Eton O, Legha SS, Bedikian AY, et al. Sequential biochemotherapy versus chemotherapy for metastatic melanoma: results from a phase III randomized trial. J Clin Oncol 2002;20:2045-52.

[11] Atkins MB, Hsu J, Lee S, et al. Phase III trial comparing concurrent biochemotherapy with cisplatin, vinblastine, dacarbazine, interleukin2 , and interferon alfa- $2 \mathrm{~b}$ with cisplatin, vinblastine, and dacarbazine alone in patients with metastatic malignant melanoma (E3695): a trial coordinated by the Eastern Cooperative Oncology Group. J Clin Oncol 2008;26:5748-54.

[12] Bajetta E, Del Vecchio M, Nova P, et al. Multicenter phase III randomized trial of polychemotherapy (CVD regimen) versus the same chemotherapy (CT) plus subcutaneous interleukin-2 and interferonalpha2b in metastatic melanoma. Ann Oncol 2006;17:571-7.

[13] Keilholz U, Punt CJ, Gore M, et al. Dacarbazine, cisplatin, and interferon-alfa-2b with or without interleukin-2 in metastatic melanoma: a randomized phase III trial (18951) of the European Organisation for Research and Treatment of Cancer Melanoma Group. J Clin Oncol 2005;23:6747-55.

[14] Ridolfi R, Chiarion-Sileni V, Guida M, et al. Cisplatin, dacarbazine with or without subcutaneous interleukin-2, and interferon alpha- $2 \mathrm{~b}$ in advanced melanoma outpatients: results from an Italian multicenter phase III randomized clinical trial. J Clin Oncol 2002;20:1600-7.

[15] Zheng YW, Li RM, Zhang XW, Ren XB. Current adoptive immunotherapy in non-small cell lung cancer and potential influence of therapy outcome. Cancer Invest 2013;31:197-205.

[16] Lafferty KJ, Prowse SJ, Al-Adra A, Warren HS, Vasalli J, Reich E. An improved assay for interleukin 2 (lymphocyte growth factor) produced by mitogen-activated lymphocytes. Aust J Exp Biol Med Sci 1980;58:533-44

[17] Viganò S, Perreau M, Pantaleo G, Harari A. Positive and negative regulation of cellular immune responses in physiologic conditions and diseases. Clin Dev Immunol 2012;2012:4857-81. 
[18] Schwartz RHA. Cell culture model for T lymphocyte clonal anergy. Science 1990;248:1349-56.

[19] Pardoll DM. The blockade of immune checkpoints in cancer immunotherapy. Nat Rev Cancer 2012;12:252-64.

[20] Mellman I, Coukos G, Dranoff G. Cancer immunotherapy comes of age. Nature 2011;480:480-9.

[21] Weiner LM, Surana R, Wang S. Monoclonal antibodies: versatile platforms for cancer immunotherapy. Nat Rev Immunol 2010;10:317-27.

[22] Keir ME, Butte MJ, Freeman GJ, Sharpe AH. PD-1 and its ligands in tolerance and immunity. Annu Rev Immunol 2008;26:677-704.

[23] Lenschow DJ, Walunas TL, Bluestone JA. CD28/B7 system of T cell costimulation. Annu Rev Immunol 1996;14:233-58.

[24] Schwartz RH. Costimulation of T lymphocytes: the role of CD28, CTLA-4, and B7/BB1 in interleukin-2 production and immunotherapy. Cell 1992;71:1065-8.

[25] Chen L, Ashe S, Brady WA, et al. Costimulation of antitumor immunity by the $\mathrm{B} 7$ counter receptor for the T lymphocyte molecules CD28 and CTLA-4. Cell 1992;71:1093-102.

[26] Townsend SE, Allison JP. Tumor rejection after direct costimulation of CD8+ T cells by B7-transfected melanoma cells. Science 1993;259:368-70.

[27] Linsley PS, Brady W, Urnes M, Grosmaire LS, Damle NK, Ledbetter JA. CTLA-4 is a second receptor for the B cell activation antigen B7. J Exp Med 1991;174:561-9.

[28] Tai X, Van Laethem F, Sharpe AH, Singer A. Induction of autoimmune disease in CTLA-4-/- mice depends on a specific CD28 motif that is required for in vivo costimulation. Proc Natl Acad Sci U S A 2007;104:13756-61.

[29] Nishimura H, Nose M, Hiai H, Minato N, Honjo T. Development of lupus-like autoimmune diseases by disruption of the PD-1 gene encoding an ITIM motif-carrying immunoreceptor. Immunity 1999;11:141-51.

[30] Okazaki T, Honjo T. PD-1 and PD-1 ligands: from discovery to clinical application. Int Immunol 2007;19:813-24.

[31] Long EO. Regulation of immune responses through inhibitory receptors. Annu Rev Immunol 1999;17:875-904.

[32] Sidorenko SP, Clark EA. The dual-function CD150 receptor subfamily: the viral attraction. Nat Immunol 2003:4:19-24.

[33] Raimondi G, Zanoni I, Citterio S, Ricciardi-Castagnoli P, Granucci F. Induction of peripheral $\mathrm{T}$ cell tolerance by antigen-presenting $\mathrm{B}$ cells. II. Chronic antigen presentation overrules antigen-presenting B cell activation. J Immunol 2006;176:4021-8.

[34] Freeman GJ, Long AJ, Iwai Y, et al. Engagement of the PD-1 immunoinhibitory receptor by a novel B7 family member leads to negative regulation of lymphocyte activation. J Exp Med 2000;192:1027-34.

[35] Greenwald RJ, Freeman GJ, Sharpe AH. The B7 family revisited. Annu Rev Immunol 2005;23:515-48.

[36] Kinter AL, Godbout EJ, McNally JP, et al. The common $\gamma$ chain cytokines IL-2, IL-7, IL-15, and IL-21 induce the expression of programmed death-1 and its ligands. J Immunol 2008;181: 6738-46.

[37] Latchman YE, Liang SC, Wu Y, et al. PD-L1-deficient mice show that PD-L1 on T cells, antigen-presenting cells, and host tissues negatively regulates T cells. Proc Natl Acad Sci U S A 2004;101:10691-6.

[38] Tivol EA, Borriello F, Schweitzer AN, Lynch WP, Bluestone JA, Sharpe AH. Loss of CTLA-4 leads to massive lymphoproliferation and fatal multiorgan tissue destruction, revealing a critical negative regulatory role of CTLA-4. Immunity 1995;3:541-7.

[39] Latchman Y, Wood CR, Chernova T, et al. PD-L2 is a second ligand for PD-1 and inhibits T cell activation. Nat Immunol 2001;2: 261-8.

[40] Dong H, Zhu G, Tamada K, Chen L. B7-H1, a third member of the B7 family, co-stimulates T-cell proliferation and interleukin-10 secretion. Nat Med 1999;5:1365-9.

[41] Tseng SY, Otsuji M, Gorski K, et al. B7-DC, a new dendritic cell molecule with potent costimulatory properties for T cells. J Exp Med 2001;193:839-46.
[42] Matsumoto K, Inoue H, Nakano T, et al. B7-DC regulates asthmatic response by an IFN-gamma-dependent mechanism. J Immunol 2004;172:2530-41.

[43] Saresella M, Rainone V, Al-Daghri NM, Clerici M, Trabattoni D. The PD-1/PD-L1 pathway in human pathology. Curr Mol Med 2012;12:259-67.

[44] Yu MC, Chen CH, Liang X, et al. Inhibition of T-cell responses by hepatic stellate cells via B7-H1-mediated T-cell apoptosis in mice. Hepatology 2004;40:1312-21.

[45] Dong H, Chen L. B7-H1 pathway and its role in the evasion of tumor immunity. J Mol Med 2003;81:281-7.

[46] Dong H, Strome SE, Salomao DR, et al. Tumor-associated B7-H1 promotes T-cell apoptosis: a potential mechanism of immune evasion. Nat Med 2002;8:793-800.

[47] Hino R, Kabashima K, Kato Y, et al. Tumor cell expression of programmed cell death-1 ligand 1 is a prognostic factor for malignant melanoma. Cancer 2010;116:1757-66.

[48] Hamanishi J, Mandai M, Iwasaki M, et al. Programmed cell death 1 ligand 1 and tumor-infiltrating CD8+ T lymphocytes are prognostic factors of human ovarian cancer. Proc Natl Acad Sci U S A 2007; 104:3360-5.

[49] Konishi J, Yamazaki K, Azuma M, Kinoshita I, Dosaka-Akita H, Nishimura M. B7-H1 expression on non-small cell lung cancer cells and its relationship with tumor-infiltrating lymphocytes and their PD-1 expression. Clin Cancer Res 2004;10:5094-100.

[50] Thompson RH, Gillett MD, Cheville JC, et al. Costimulatory B7-H1 in renal cell carcinoma patients: indicator of tumor aggressiveness and potential therapeutic target. Proc Natl Acad Sci U S A 2004;101:17174-9.

[51] Nakanishi J, Wada Y, Matsumoto K, Azuma M, Kikuchi K, Ueda S. Overexpression of B7-H1 (PD-L1) significantly associates with tumor grade and postoperative prognosis in human urothelial cancers. Cancer Immunol Immunother 2007;56:1173-82.

[52] Strome SE, Dong H, Tamura H, et al. B7-H1 blockade augments adoptive T-cell immunotherapy for squamous cell carcinoma. Cancer Res 2003;63:6501-5.

[53] Lyford-Pike S, Peng S, Young GD, et al. Evidence for a role of the PD-1:PD-L1 pathway in immune resistance of HPV-associated head and neck squamous cell carcinoma. Cancer Res 2013;73:1733-41.

[54] Ohigashi Y, Sho M, Yamada Y, et al. Clinical significance of programmed death-1 ligand-1 and programmed death-1 ligand2 expression in human esophageal cancer. Clin Cancer Res 2005; 11:2947-53

[55] Karim R, Jordanova ES, Piersma SJ, et al. Tumor-expressed B7-H1 and B7-DC in relation to PD-1+ T-cell infiltration and survival of patients with cervical carcinoma. Clin Cancer Res 2009;15:6341-7.

[56] Ghebeh H, Mohammed S, Al-Omair A, et al. The B7-H1 (PD-L1) T lymphocyte-inhibitory molecule is expressed in breast cancer patients with infiltrating ductal carcinoma: correlation with important high-risk prognostic factors. Neoplasia 2006;8:190-8.

[57] Nomi T, Sho M, Akahori T, et al. Clinical significance and therapeutic potential of the programmed death-1 ligand/programmed death-1 pathway in human pancreatic cancer. Clin Cancer Res 2007;13: 2151-7.

[58] Wu C, Zhu Y, Jiang J, Zhao J, Zhang XG, Xu N. Immunohistochemical localization of programmed death-1 ligand-1 (PD-L1) in gastric carcinoma and its clinical significance. Acta Histochem 2006;108: $19-24$.

[59] Routh JC, Ashley RA, Sebo TJ, et al. B7-H1 expression in Wilms tumor: correlation with tumor biology and disease recurrence. J Urol 2008;179:1954-9.

[60] Wintterle S, Schreiner B, Mitsdoerffer M, et al. Expression of the B7related molecule $\mathrm{B} 7-\mathrm{H} 1$ by glioma cells: a potential mechanism of immune paralysis. Cancer Res 2003;63:7462-7.

[61] Hirano F, Kaneko K, Tamura H, et al. Blockade of B7-H1 and PD1 by monoclonal antibodies potentiates cancer therapeutic immunity. Cancer Res 2005;65:1089-96. 
[62] Cho YA, Yoon HJ, Lee JI, Hong SP, Hong SD. Relationship between the expressions of PD-L1 and tumor-infiltrating lymphocytes in oral squamous cell carcinoma. Oral Oncol 2011;47:1148-53.

[63] Khalili JS, Hwu P, Lizée G. Oncogenic BRAF(V600E) promotes stromal cell-mediated immunosuppression via induction of interleukin-1 in melanoma. Clin Cancer Res 2012;18:5329-40.

[64] Ahmadzadeh M, Johnson LA, Heemskerk B, et al. Tumor antigenspecific CD8 T cells infiltrating the tumor express high levels of PD-1 and are functionally impaired. Blood 2009;114:1537-44.

[65] Gadiot J, Hooijkaas AI, Kaiser AD, van Tinteren H, van Boven H, Blank C. Overall survival and PD-L1 expression in metastasized malignant melanoma. Cancer 2011;117:2192-201.

[66] Taube JM, Anders RA, Young GD, et al. Colocalization of inflammatory response with B7-h1 expression in human melanocytic lesions supports an adaptive resistance mechanism of immune escape. Sci Transl Med 2012;4:127-37.

[67] Topalian SL, Hodi FS, Brahmer JR, et al. Safety, activity, and immune correlates of anti-PD-1 antibody in cancer. N Engl J Med 2012;366:2443-54.

[68] Hodi FS, Sznol M, McDermott DF, et al. Clinical activity and safety of anti-PD-1 (BMS-936558, MDX-1106) in patients with advanced melanoma (MEL). In: 2012 ASCO annual meeting. 2012. J Clin Oncol 30 [suppl; abstr 8507].

[69] Hamid O, Robert C, Daud A, et al. Safety and tumor responses with lambrolizumab (anti-PD-1) in melanoma. N Engl J Med 2013;369:134-44.

[70] Brahmer JR, Tykodi SS, Chow LQ, et al. Safety and activity of antiPD-L1 antibody in patients with advanced cancer. N Engl J Med 2012;366:2455-65.

[71] Mkrtichyan M, Najjar YG, Raulfs EC, et al. B7-DC-Ig enhances vaccine effect by a novel mechanism dependent on PD-1 expression level on T cell subsets. J Immunol 2012;189:2338-47.

[72] Slingluff Jr CL. The present and future of peptide vaccines for cancer: single or multiple, long or short, alone or in combination? Cancer J 2011;17:343-50.

[73] Rosenblatt J, Glotzbecker B, Mills H, et al. PD-1 blockade by CT-011, anti-PD-1 antibody, enhances ex vivo T-cell responses to autologous dendritic cell/myeloma fusion vaccine. J Immunother 2011;34:409-18.

[74] Pilon-Thomas S, Mackay A, et al. Blockade of programmed death ligand 1 enhances the therapeutic efficacy of combination immunotherapy against melanoma. J Immunol 2010;184:3442-9.

[75] Li N, Qin H, Li X, et al. Potent systemic antitumor immunity induced by vaccination with chemotactic-prostate tumor associated antigen gene-modified tumor cell and blockade of B7-H1. J Clin Immunol 2007;27:117-30.

[76] Palazón A, Teijeira A, Martínez-Forero I, et al. Agonist anti-CD137 $\mathrm{mAb}$ act on tumor endothelial cells to enhance recruitment of activated T lymphocytes. Cancer Res 2011;71:801-11.

[77] Curran MA, Montalvo W, Yagita H, Allison JP. PD-1 and CTLA-4 combination blockade expands infiltrating $\mathrm{T}$ cells and reduces regulatory $\mathrm{T}$ and myeloid cells within B16 melanoma tumors. Proc Natl Acad Sci U S A 2010;107:4275-80.

[78] Wolchok JD, Kluger H, Callahan MK, et al. Nivolumab plus ipilimumab in advanced melanoma. N Engl J Med 2013;369:122-33.

[79] Thompson RH, Kuntz SM, Leibovich BC, et al. Tumor B7-H1 Is Associated with Poor Prognosis in Renal Cell Carcinoma Patients with Long-term Follow-up. Cancer Res 2006;66:3381-5.

[80] Mu CY, Huang J-A, Chen Y, Chen C, Zhang X-G. High expression of PD-L1 in lung cancer may contribute to poor prognosis and tumor cells immune escape through suppressing tumor infiltrating dendritic cells maturation. Med Oncol 2011;28:682-8.

[81] Gao Q, Wang X-Y, Qiu S-J, et al. Overexpression of PD-L1 Significantly associates with tumor aggressiveness and postoperative recurrence in human hepatocellular carcinoma. Clin Cancer Res 2009;15:971-9.

[82] Cariani E, Pilli M, Zerbini A, et al. Immunological and molecular correlates of disease recurrence after liver resection for hepatocellular carcinoma. PLoS ONE 2012;7:e32493.
[83] Zeng Z, Shi F, Zhou L, et al. Upregulation of circulating PD-L1/PD 1 is associated with poor post-cryoablation prognosis in patients with HBV-related hepatocellular carcinoma. PLoS ONE 2011;6:e23621.

[84] Hsu MC, Hsiao JR, Chang KC, Wu YH, Su IJ, Jin YT. Increase of programmed death-1 expressing intratumoral CD8 T cells predicts a poor prognosis for nasopharyngeal carcinoma. Mod Pathol 2010;23:1393-403.

[85] Droeser RA, Hirt C, Viehl CT, Frey DM, et al. Clinical impact of programmed cell death ligand 1 expression in colorectal cancer. Eur J Cancer 2013.

[86] Wahlin BE, Aggarwal M, Montes-Moreno S, et al. A unifying microenvironment model in follicular lymphoma: outcome is predicted by programmed death-1 positive, regulatory, cytotoxic, and helper T cells and macrophages. Clin Cancer Res 2010;16:637-50.

[87] Takahashi H, Tomita N, Sakata S, et al. Prognostic significance of programmed cell death-1-positive cells in follicular lymphoma patients may alter in the rituximab era. Eur J Haematol 2013;90:286-90.

[88] Richendollar BG, Pohlman B, Elson P, Hsi ED. Follicular programmed death 1-positive lymphocytes in the tumor microenvironment are an independent prognostic factor in follicular lymphoma. Hum Pathol 2011;42:552-7.

[89] Muenst S, Hoeller S, Dirnhofer S, Tzankov A. Increased programmed death-1+ tumor-infiltrating lymphocytes in classical Hodgkin lymphoma substantiate reduced overall survival. Hum Pathol 2009; 40:1715-22.

[90] Shi F, Shi M, Zeng Z, et al. PD-1 and PD-L1 upregulation promotes CD8(+) T-cell apoptosis and postoperative recurrence in hepatocellular carcinoma patients. Int J Cancer 2011;128:887-96.

[91] Brahmer JR, Drake CG, Wollner I, et al. Phase I study of single-agent anti-programmed death-1 (MDX-1106) in refractory solid tumors: safety, clinical activity, pharmacodynamics, and immunologic correlates. J Clin Oncol 2010;28:3167-75.

[92] Berger R, Rotem-Yehudar R, Slama G, et al. Phase I safety and pharmacokinetic study of CT-011, a humanized antibody interacting with PD-1, in patients with advanced hematologic malignancies. Clin Cancer Res 2008;14:3044-51.

[93] McDermott DF, Drake CG, Sznol M, et al. Clinical activity and safety of anti-PD-1 (BMS-936558, MDX-1106) in patients with previously treated metastatic renal cell carcinoma (mRCC). In: 2012 ASCO annual meeting. 2012. J Clin Oncol 30 [suppl; abstr 4505].

[94] Patnaik A, Kang SP, Tolche AW, et al. Phase I study of MK-3475 (antiPD-1 monoclonal antibody) in patients with advanced solid tumors. In: 2012 ASCO annual meeting. 2012. J Clin Oncol 30 [suppl; abstr 2512].

[95] Kudchadkar RR, Gallenstein D, Martinez AJ, et al. Phase I trial of extended-dose anti-PD-1 antibody BMS-936558 with a multipeptide vaccine for previously treated stage IV melanoma. In: 2012 ASCO annual meeting. 2012. J Clin Oncol 30 [suppl; abstr 8582].

[96] Brahmer JR, Horn L, Antonia S, et al. Clinical activity and safety of anti-PD1 (BMS-936558, MDX-1106) in patients with advanced nonsmall-cell lung cancer (NSCLC). In: 2012 ASCO annual meeting. 2012. J Clin Oncol 30 [suppl; abstr 7509].

[97] Tykodi SS, Brahmer JR, Hwu W-J, et al. PD-1/PD-L1 pathway as a target for cancer immunotherapy: safety and clinical activity of BMS936559, an anti-PD-L1 antibody, in patients with solid tumors. In: 2012 ASCO annual meeting. 2012. J Clin Oncol 30 [suppl; abstr 2510].

\section{Biographies}

Daniela Massi, MD, $\mathrm{PhD}$, is Associate Professor of Pathology at the University of Florence Medical School, Italy. Her pathology training includes a Dermatopathology fellowship at the Institute for Dermatopathology, Thomas Jefferson University, Philadelphia, PA, under the direction 
of A. Bernard Ackerman. She then received a Post-Doctoral Research fellowship from the American-Italian Cancer Foundation (A.I.C.F.) with a research program in cutaneous melanoma. She has been member of the Executive Committee of the International Society of Dermatopathology (1997-2003), Chairman of the Dermatopathology Working Group of the European Society of Pathology (2007-2011), and she is currently member of the EORTC Melanoma Pathology Group. She is Associate Editor of Virchows Archiv and scientific reviewer for several international scientific journals. Her research interests are focused on skin tumor pathology, and particularly receptor signaling and molecular genetics of melanoma. She has authored more than 200 publications and contributed to the volume 'Pathology \& Genetics of Skin Tumours' of the World Health Organization (WHO) Classification of Tumours series.

Mario Mandalà is currently a Medical Oncologist in the Unit of Medical Oncology, Papa Giovanni XXIII
Hospital in Bergamo, Italy. He is in charge of the Clinical and Traslational Research Unit. He received his MD from the Catholic University in Rome, Italy in 1995. He has completed residencies in Medical Oncology at the Catholic University in Rome as well as at Milan University and the European Institute of Oncology in Milan, Italy. He also obtained diplomas in Medical Oncology and Hematology from Milan University in 2000 and 2005, respectively. His research interests include clinical and translational research on cancer and thrombosis. His main oncological research focuses on gastrointestinal cancer and melanoma. He is a full member of the European Society of Medical Oncology. He has lead- or co-authored many scientific papers and is a reviewer for several journals, including Lancet Oncology, Cancer, British Journal of Cancer, Annals of Oncology, Cancer Treatment Review, Journal of Thrombosis and Hemostasis, Thrombosis and Hemostasis, Arteriosclerosis-Thrombosis and Vascular Biology, Critical Reviews in Oncology and Hematology. 